Araştırma Makalesi

\title{
Milliyetçilik Bağlamında Bahoz/FIrtına Filminin Söylem Analizi
}

\author{
Şükrü Sim (Doç. Dr.) \\ İstanbul Üniversitesi İletişim Fakültesi \\ sukrisim@istanbul.edu.tr \\ Orcid: 0000-0003-3579-6750 \\ Semih Göncü \\ İstanbul Üniversitesi Sosyal Bilimler Enstitüsü \\ sgoncu38@gmail.com \\ Orcid: 0000-0001-6528-0494
}

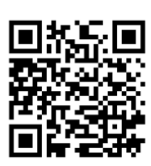

Başvuru Tarihi: 21.10.2018

Yayına Kabul Tarihi: 29.11.2018

Yayınlanma Tarihi: 21.01.2019

\section{Öz}

$\mathrm{Bu}$ çalışma sinema ve milliyetçilik ilişkisinin irdelenmesine dair literatüre bir katkı sağlama amacındadır. Çalışmada bu kapsamda Kazım Öz'ün 2008 yılında gösterime giren Bahoz / Fırtına filmi milliyetçilik bağlamında söylem analizine tabi tutulacaktır. Bu filmin seçilme nedeni ise gerek işlediği konunun gerekse yönetmenin açıklamalarının Kürt milliyetçiliğine dair söylemsel bir yapıya işaret etmesinden kaynaklanmaktadır. Çünkü yönetmen Kazım Öz "Kürt Sineması" icra ettiğini ifade ederek, sinemasını mevcut bilinen sinema pratiklerinden ayrı bir noktada konumlandırmaktadır. Bununla beraber film 1990'ların yoğun politik atmosferinde geçmekte ve Kürt siyasi hareketinin üniversite ayağını anlatısının merkezine yerleştirmektedir. Dolayısıyla film, Kürt milliyetçiliği ve sinema ilişkisinin irdelenmesine dair uygun bir yapı sağlamaktadır. Çalışmada Kürt milliyetçiliği ve sinema ilişkisinin irdelenme sebeplerinden birisi de mevcut Türkçe literatürde bu alanda bir eksiklik bulunmasından dolayıdır. Zira Türk milliyetçiliği ve sinema ilişkisine dair birçok çalışma bulunurken, Kürt milliyetçiliği ve sinema ilişkisini doğrudan ele alan bir çalışma bulunmamaktadır. Çalışmada kuramsal zeminin sağlanması için öncelikle, milliyetçilik ve Kürt milliyetçiliği farklı kuramcılar eşliğinde açıklanmıştır. Akabinde filmdeki söylemsel yapıyı ortaya çıkartmak için gerekli teknik olan Teun Van Dijk'ın söylem analiz modeli açıklanmış ve film bu modele göre çözümlenmeye çalışılmıştır. Filmdeki söylem yapısının Kürt milliyetçiliğine dair söyleme uyduğu tespit edilmekle birlikte, milliyetçiliğe dair kuramcıların ifade ettiği çeşitli görüşlerin de film içinde onaylandığı görülmüştür.

Anahtar Sözcükler: Milliyetçilik, Kürt Milliyetçiliği, Sinema ve Milliyetçilik, Bahoz / Fırtına, Söylem Analizi. 
Research Article

\title{
The Discourse Analysis of the Bahoz/Storm In the Context of Nationalism
}

\author{
Şükrü Sim (Assoc. Prof Dr.) \\ İstanbul University Faculty of Communication \\ sukrisim@istanbul.edu.tr \\ Orcid: 0000-0003-3579-6750 \\ Semih Göncü \\ İstanbul University Institute of Social Sciences \\ sgoncu38@gmail.com \\ Orcid: 0000-0001-6528-0494
}

Date Received: 21.10.2018

Date Accepted: 29.11.2018

Date Published: 21.01.2019

\begin{abstract}
The purpose of this study is to make a contribution to the examination of the relationship between cinema and nationalism. Hence, The Bahoz / Storm film which was directed by Kazım Öz in 2008, is subject to discourse analysis in the context of nationalism. The reason for choosing this film is that it points to a discursive structure of Kurdish nationalism. Because Kazım Öz expressed various times which he considers his films in "Kurdish Cinema". Hence, Öz places his cinema in a separate position that the other known cinema practices. In addition to that the film's narrative centres around Kurdish youth movement. Therefore, the film provides a convenient structure for examining the relationship between Kurdish nationalism and cinema. One of the reasons for examining the relationship between Kurdish nationalism and cinema is that there is a deficiency in the current Turkish literature about this issue. While there are many studies on the relationship between Turkish nationalism and cinema, there is no study which directly deals with the relationship between Kurdish nationalism and cinema. First, nationalism and Kurdish nationalism are explained in the context of different theorists in order to provide the theoretical framework in the study. Subsequently, Teun Van Dijk's discourse analysis, which is a method for unveiling discourses in texts, is explained and the film is analyzed accordingly. The Kurdish nationalist discourse of the film has been confirmed. In addition to that, the various views expressed by the theoreticians of nationalism have also been confirmed by the film itself.
\end{abstract}

Keywords: Nationalism, Kurdish Nationalism, Cinema and Nationalism, The Storm / Bahoz, Discourse Analysis. 


\section{Giriş}

Günümüz dünyasında milliyetçilik etrafında yoğun tartışmalar yaşanmaktadır. Bunun en önemli sebebi kuşkusuz, dünyanın birçok bölgesinde yaşanan etnik ve milliyetçi kökenli çatışmalardır. Bununla birlikte küreselleşmenin ulus devletleri sorgulanır bir vaziyete taşıması, etnik kimliklerin daha görünür bir duruma evirilmesi, milliyetçilik ile ilgili tartışmaları yoğunlaştırmıştır. $\mathrm{Bu}$ ve benzer sebeplerle milliyetçilik günümüzde hâlen akademik çalışmalarda (farklı disiplinlerde) yoğun bir şekilde irdelenmekte ve tartışılmaktadır. Dolayısıyla milliyetçilik etrafında geniş bir literatür bulunmaktadır (Yıldırım, 2011, 11-14). Bu anlamda milliyetçiliğin sinemadaki etkilerini araştırmak ve tartışmak ise, film araştırmacılarına düşmektedir. Zira sinema gibi temsil gücü son derece yüksek bir araçta milliyetçilik gibi bir konuyu araştırmak hem sinemanın gücünü daha iyi idrak etmemiz hem de milliyetçiliğin etkilerini görmemiz açısından önemli olacaktır. Çünkü "filmler herhangi bir durumu yansıtmaktan çok o durumun tasarlanan belli bir biçimini oluşturmak üzere seçilmiş ve birleştirilmiş temsili öğeler yoluyla birtakım tezler ileri sürer, bunu yaparken, seyirciye belli bir konumu ya da bakıș açısını telkin ederler" (Ryan ve Kellner, $2010,18)$. Bir filmde telkin edilen anlamları ortaya çıkartmanın, film araştırmaları açısından büyük bir önem arz ettiği söylenebilir. Filmlerde üretilen anlamları ise, film kuramcısı Peter Wollen'ın da ifade ettiği gibi $(2012,129)$ ancak diğer anlamlarla ilişkili olarak açıklayabiliriz. Bu perspektiften hareket eden çalışma, milliyetçi unsurlara sahip olduğu düşünülen bir filmde telkin edilen anlamları ortaya çıkartma amacındadır. Çalışmada Kazım Öz'ün 2008 yılında gösterime giren Bahoz/Fırtına filmi milliyetçilik bağlamında çözümlenecektir. Film, 1990’larda üniversitede faaliyet gösteren Kürt siyasî hareketini anlatısına yerleștirmekte ve bunun üzerinden dağa çıkış sürecini ele almaktadır. Film, yönetmeni tarafından "Kürt Sineması" ismi altında tanımlanmaktadır (Göncü, 2016, 77). ${ }^{1}$ Filmin bu anlamda milliyetçi, bilhassa Kürt milliyetçiliğine dair bir yapı ihtiva ettiği düşünülmektedir. Çalışmanın odak noktası da bu yapıyı ortaya çıkartmak ve tartışmaktır.

Çalışmaya kuramsal arka plan sağlamak için milliyetçilik ve Kürt milliyetçiliği, çeşitli kuramcıların görüşleri çerçevesinden açıklanmaya çalışılacaktır. Akabinde sinema ve milliyetçilik ilişkisine değinilerek, çalışmanın önemine değinilecek ve filmin analizine geçilecektir. Film, Teun Van Dijk'ın söylem analizi tekniği ile çözümlenmeye çalışılarak bir sonuca ulaşılmaya çalışılacaktır.

\section{Ulus ve Milliyetçilik}

Dilimizde ulus/millet olarak anılan kelimelerin ilk kullanımlarına ve köklerini Roma toplumunda, Romalı olmayan grupları tanımlamak için kullanılan "natio" ifadesinde rastlarken, Orta çağda bu sözcük "nationes" şeklinde üniversitelerde öğrencilerin geldikleri ülkelere göre taksim edilmesinde kullanılmaktaydı. Daha sonrasında ise coğrafî hareketlenmelerin de artması ile ülke içinde çeşitli ayrımları yapmak için başvurulan bir kelime hâlini almıştır (Habermas, 2015, 18). Modern dönemin hemen öncesinde ise ulus (nation) “(...) yalnızca aynı kültürü paylaşan ve hemşehri olan insanları tanımlamak için" kullanılmaktaydı (Kedourie'den akt. Calhoun, 2012, 13). Modern dönemde ise anlamsal ve işlevsel olarak ciddi değişiklikler göstermiştir. ${ }^{2}$

Modern dönemde ortaya çıktığı bilinen ulus ve milliyetçilik kavramları her bakımdan tanımlaması güç kavramlardır. Bu durumu ulus üzerine uzun çalışmalar yürüten Hugh Seton Watson da doğrulamaktadır. Watson'a göre $(1977,5)$ ortada ulus gibi 
çok güçlü bir fenomen olmasına rağmen, bu kavramı bilimsel olarak tanımlamak pek mümkün değildir. Watson'ın konu üzerine bulduğu en makul açıklamalardan biri ise, önemli bir sayıda insan topluluğunun kendisini "ulus" olarak görmeye veya tek bir "güç" gibi hareket etmeye başladıkları anda bir ulus sayılabileceğidir. Bu noktada zihinde oluşan soru ise ulusun nasıl oluştuğudur. Bunun için milliyetçilik kavramını irdelemek gerekmektedir. İdeolojik bir hareket olarak milliyetçilik ideolojisinin ortaya çıkışı ve bunun sonucu olarak ulusların doğuşu çeşitli araştırmacılara göre değişebilmektedir. Örneğin kimi araştırmacılar ulusların doğuşunu 18. yüzyılın öncesine götürürken, bir kısım araştırmacı da 19. yüzyıl sonu ve 20. yüzyılın başına kadar götürmektedirler. Birçok araştırmacıdaki ortak kanaat ise ulusların oluşumunda önemli bir etken olan milliyetçiliğin, Fransız Devrimi (1789) ile ortaya çıktığı ve öncesinde millî hissiyata dair geçen çeşitli görüşlerin, ifadelerin ve olayların müphem nitelikler taşıdığıdır (Smith, 1994, 76-77). Yıldırım ise $(2011,12$, 21-22), milliyetçiliğin modern dönem öncesinde kavmiyetçilik olarak var olduğunu iddia eder. Örneğin Heredot dünyayı Yunanlar ve Yunanlı olmayanlar șeklinde ikiye ayırarak, Yunan topluluğuna ayrıcalıklı ve üstün bir statü vermektedir. Keza Platon ve Aristo da dünyayı Grekler ve Barbarlar olarak ikiye ayırmaktaydı. Diğer taraftan modern milliyetçilik ise Elie Kedourie'ye göre 19. yüzyılın başlarında Avrupa'da üretilmiş bir doktrindir. Buna göre nüfusun yönetimde söz sahibi olacak kısmını belirlemeye, devlet gücünü meşru bir şekilde kullanmaya ve devletler topluluğunun düzgün işleyişine kriterler sunar gibi gözükür. Özetle söz konusu ideoloji insanlığın uluslara ayrıldığını, ulusların kendisine ait ulusal kimliklere sahip olduğu ve tek meşru yönetim biçiminin ise, ulusun kendi kendisini yönettiği sistem olduğunu savunur (Akt. Calhoun, 2012, 16). Bu anlamda ulusu inşa eden güç ise Ernest Gellner'ın da (1992) savunduğu gibi milliyetçilik olmaktadır. Dolayısıyla milliyetçilik ulusların ürünü değil; bilakis ulusu meydana getiren olgudur. Gellner'a göre milliyetçilik önceden beri var olan çok sayıdaki kültür arasından bir seçim yapar ve onları kendi ideolojisine uygun bir vaziyete sokar. Egemen bir üst kültür inşa edilir: Örneğin ölü diller canlandırılır, gelenekler icat edilir, çok eskiye ait olduğu söylenen bazı saf nitelikler gündeme getirilir. Yapılmaya çalışılan bir tür toplumsal hafıza inşasıdır. Milliyetçilik bu bağlamda tarihten, hatta mitolojiden bir hayli yararlanır. Diğer uluslardan üstün, kahramanlıklarla dolu bir tarihe sahip olunduğu vurgulanır. Mesela 1796 senesinde Vicom de Bonald, Fransız diline, dinine, tarihine, kültürüne büyük övgüler düzer. Benzer övgülere İtalyan ve İngiliz milliyetçilerinde de rastlamak mümkündür (Yıldırım, 2011, 26).

Ulus inşasında dikkat çeken unsurlardan biri ise dildir. Ernest Gellner (1992) kuramında dilin gücüne ve standartlaştırılmasına dikkat çeker. Ona göre, örneğin iki insan aynı kültürü; yani aynı düșünceleri, ișaretleri, kısacası benzer bir iletişim sistemini paylaşıyorsa aynı ulustan kabul edilebilir. Zira her şeyden önce topluluğun bir ulus oluşturabilmesi için kendi içinde birbirini anlamaya ihtiyacı bulunmaktadır. Gellner, sanayi devriminden sonra toplumu eğitmenin tamamen devletin tekeline geçtiğini ve bu eğitim aracılığıyla dillerin standartlaştırıldığını belirtir. Benzer şekilde Eric Hobsbawn da dilin gücüne dikkat çekmektedir. Hobsbawn'a göre $(1993,70)$ dil "biz ve onlar" ayrımını gerçekleştiren, yani kimliği oluşturan en önemli unsurlardan biridir. Aynı dili konuşanlar kendilerini “biz" olarak görebilirken, kendileri ile aynı dili konuşmayanları "onlar" olarak hatta "barbar" olarak tanımlayabilirler. Bir bakıma aynı dili konuşanlar kendilerini yüceltirken, ötekini küçültmektedir. Bu bağlamda düşünüldügünde milliyetçilik ideolojisi dostlar ve düşmanlar ayrımıyla karşıtlıklar 
da üretebilmektedir. Dostlar ortak duyguları, ruhu, vatanı, tarihi paylaşanlardır. Potansiyel düşmanlar ise, öteki milletlerden gelen farklı tarihsel ve kültürel varoluş biçimleridir (Yıldırım, 2011, 35-36).

Milliyetçilik konusundaki bir diğer önemli kuramcı Benedict Anderson da dilin önemine dikkat çekmektedir. Anderson'a göre ulus hayal edilerek inşa edilmiş bir cemaattir. Sınırları ve egemenlik alanı ise, kendisine mündemiç olacak şekilde hayal edilmiştir. Anderson'a göre hayatında birbirini hiç görmemiş ve tanışmayacak olan milyonlarca insan, kendisini bir bütünün parçası olarak görmektedirler ve aralarında bir bağ olduğunu bilmektedirler. Hatta bu insanlar aralarındaki bağın korunması için gerekirse savaşmayı; ölmeyi ve öldürmeyi dahi göze almaktadırlar. Dolayısıyla ulus kavramı insanların zihnindeki bir imgeden ibarettir. Söz konusu imge ise belli bir egemenlik alanı ve sınırı üzerine bina/inşa edilmiștir. Anderson'a göre ulus biyolojik bir akrabalıktan ziyade dilden hayal edilmektedir (2011, 20$21,151,163)$.

Ulusların doğrudan sonucunun ise, ulus devletler olduğu söylenebilir. Gellner'a göre milliyetçi ideoloji, ulus ile devletin birbirinin nasibi olduğunu; biri olmadan diğerinin eksik olacağını, aksinin trajik bir durum olduğunu savunmaktadır. Zira milliyetçi akımlar ekseriyetle bağımsız bir ulus devlete kavuşmak isterler $(1992,27$, 87). Nitekim Hobsbawn da "Millet ancak belli bir modern teritoryal devletle, 'milli devlet'le ilişkilendirildiği kadarıyla toplumsal birimdir; bununla ilişkilendirilmedikçe milleti ve milliyeti tartışmanın hiçbir yararı yoktur" $(1993,24)$ der. Anthony Smith de etnik ile ulusun farkını daha çok "bağımsız devlet" bağlamı üzerinden kurmaktadır. Smith modern bir fenomen olarak ulusun oluşumunda geçmiş etnik kimliklere, bağlılıklara dikkat çekmektedir. Ona göre mevcut etnik kimlik ne kadar güçlüyse ulus olma potansiyeli de bir o kadar yüksektir. Bunları tam olarak kavrayamadan modern anlamda ulus kavramının anlaşılamayacağını savunur. Zira günümüz uluslarının temelinde, rahatlıkla görüleceği üzere, belli bir etnik yatmaktadır. Ulus ve etnik arasında birçok benzerlik olsa da etnik topluluklarda bir ülke ile olan bağ tarihi ve sembolik bir vaziyette kalabilirken; söz konusu bağ uluslarda fiziki ve fiilidir (1994, 70-71). ${ }^{3}$ Craig Calhoun ise (2012, 6-7) ulus kabul edilmek için, diğer kuramcilar gibi, bazı ortak unsurlar belirtir (ortak tarih, kültür ve dil vs.). Ancak onun görüşünde ön plana çıkan düşünce, toplulukların ulus kabul edilmesi için geliştirdikleri retoriksel iddiadır. Bununla birlikte Calhoun, insanların kolektif projeler için harekete geçirmenin önemine işaret eder.

Bu bölümde kısaca özetlemeye çalıştığımız ulus ve milliyetçilik üzerine daha birçok kuram ve görüş bulunmaktadır. Bu kuramlar genellikle eleștirel olmakla birlikte, literatürde ön plana çıktığını varsaydığımız kuramcıların görüşlerini aktarmaya çalıştık. Milliyetçi ideolojilerin çeşitli unsurlara (tarihsel, ekonomik, toplumsal vb.) öğelere göre değiștiği söylenebilir. Bu sebeple daha özel ve tikel bağlamda irdelenmesi gerekmektedir. Dolayısıyla Kürt milliyetçiliği de ayrı bir bölüm altında irdelenmelidir.

\section{Kürt Milliyetçiliği}

Bilindiği üzere Kürt siyasî (ve silahlı) hareketleri ekseri olarak Türkiye, Irak, Suriye ve İran'da görülmektedir. Söz konusu ülkelerin içinde farklı Kürt hareketleri ortaya çıkmıştır. Mevzubahis Kürt hareketlerinin arasında bazı temel ayrımlar bulunmaktadır. Dolayısıyla her biri farklı ülke sınırları içinde faaliyet gösteren 
Kürt hareketlerinin üyeleri, Arzu Yılmaz'ın da ifade ettiği gibi daha çok parti üst kimliği ile kendilerini tanımlamaktadırlar. Zira ortada gerek siyasî sınırlar, sosyal ve kültürel farkların yol açtığı yapı, gerekse ulusal mücadele anlamında oluşan farklı deneyimler çok parçalı bir yapıya işaret etmektedir $(2015,40,46)$. Kısacası her biri farklı özellikler gösterebilen bu hareketlerin milliyetçiliklerini irdelemektense bu bölümde, çalışmamızla doğrudan ilgili olduğu için Türkiye'de filizlenen Kürt milliyetçiliğini ve bu durumu hazırlayan tarihsel ortamı, genel karakteristik özellikleri ile birlikte özetlemeye çalışacağız. Çünkü incelenecek filmde, Türkiye'deki Kürt hareketi konu alınmaktadır.

Kürt milliyetçiliğini hazırlayan ortam için kısa bir tarihsel perspektife ihtiyaç duyulmaktadır. 1639 yılında Osmanlı Devleti ile Safeviler arasında imzalanan Kasr-ı Şirin anlaşması ile birlikte, Osmanlı'nın I. Selim döneminde Kürt beyleriyle İran'a karşı yaptığı ittifak önemini yitirmiştir. Kürt beyleri etkisizleşmiş ve bunun sonucunda Kürt toplumu çeşitli sıkıntılar yaşamaya başlamıştır. Bu dönemde doğan birlik ihtiyacının izlerini, Kürt milliyetçiliğinin prototip metni sayılan, Ahmed- i Hani tarafından kaleme alınan Mem u Zin isimli eserde görmek mümkündür. Bu zamanda yaşanan hadiseler gelecekte ortaya çıkacak olan Kürt milliyetçiliğinin âdeta hazırlayıcısı konumundadır (Oran, 2008, 873). ${ }^{4}$

Modern manada Kürt milliyetçiliğinin izlerini, milliyetçilik akımlarının Osmanlı’yı etkilemeye başladığı dönemde görmek mümkündür. Kürt politik örgütler, örneğin "Kürt Teavün ve Terakki Cemiyeti" gibi (1908), 1900'lerin başlarında kurulmaya başlamıștır. Özellikle Jön Türklerin, Abdülhamid'i devirmelerinden sonra, daha Türkçü bir noktaya doğru evirilmeleri, Kürt cemiyetlerinin milliyetçi bir yapıya bürünmelerini hızlandırmıştır. Kürt coğrafyasında şeyhlerin etkisi, onların bu dönemde ön plana çıkmalarına neden olmuştur. Şeyhlerin ve Kürt hareketinin diğer ileri gelenlerinin, Bab-ı Âli'den Kürt bölgelerinde Kürtçenin resmi dil olarak kabul edilmesi, eğitim dilinin Kürtçe olması, Kürtçe konuşan devlet görevlilerinin bölgeye atanması gibi talepleri olmuştur (Jwaideh, 2014, 211- 217).

Kürt milliyetçiliği denilebilecek olguyu yaratanlar ise Kürt aydınları olmuştur. Kürt aydınlar, milliyetçiliği büyük oranda Jön Türklerden öğrenmişlerdir. Mesela bir kısım Kürt aydın, Türkçü konferansları dinleyerek Kürt olduğunun farkına varmıştır. Bu aydınlar çeşitli kültürel yayınlar yayımlamışlardır. Örneğin 1898 yılında "Kürdistan" isimli bir gazete çıkarılmıştır. 1919 yılında kurulan ve sonrasında Koçgiri ayaklanmasını çıkartacak olan Kürdistan Teali Cemiyeti'nin çıkardığı Jin dergisinde Kürtlerin kökenlerine dair çeşitli efsaneler dile getirilirken, "Biz Jön Kürtler", "Fert ölür millet yaşar", "Kürdüm iftihar ediyorum", gibi sloganlar ve kavramlar ortaya atılmıştır. Değinilen kavram ve sloganlar Kürt milliyetçiliğinin İttihat ve Terakki ideolojisinden ne denli etkilendiğini göstermektedir (Oran, 2008, 874-875). Bununla beraber Kürt aydınlar, çeşitli yayınlarla Kürtçenin modernleştirilmesi ve standartlaştırılması yönünde büyük çaba harcamışlardır (Smith, 1994, 204).

Kurtuluş Savaşında Türklerle birlikte savaşan Kürtler, cumhuriyetin kurulmasıyla birçok sorunla karşılaşmışlardır. Halifeliğin ilga edilmesi, medreselerin kapatılması, idari ve vergi reformları, Kürtler arasında hoşnutsuzluğa neden olmuştur. 1930'larda birçok Kürt isyanı çıkarken, bu isyanlar sert bir şekilde bastırılmıştır. ${ }^{5}$ Kürtlerin yaşadığı bölgelerde Türkleştirmeye yönelik asimilasyon politikaları uygulanmaya koyulurken, Kürt folklarına dair özellikler; dil, giyim vb. öğeler yasaklanmaya 
çalışılmıştır. Ayrıca çeşitli iskân politikaları devreye sokularak, nüfus yapısı değiștirilmeye çalışılmıştır. Özetle genç cumhuriyetin düșünce dünyasında; Kürtlerin Türk asıllı oldukları, dillerinin ise Farsça, Arapça ve Türkçe karışımı "ilkel" bir dil olduğu ve bu "ilkel” halkı eğitmek gerektiği düşüncesi ön plana çıkmıştır (Bruinessen, 2015, 132-133, 297, 300). 1930'lardan itibaren devlet içerisinde Türk'ten başka bir etniğin olmadığı ciddi bir şekilde savunulmaya başlanacak ve Kürtlerin de aslen "Dağ Türkleri” olduğu iddia edilecektir. Devletin çıkardığı kanun metinlerini, dönemin düşünürlerinin, devlet adamlarının açıklamalarını söylem analizine tabi tutan Mesut Yeğen'e göre, Cumhuriyetin Kuruluşundan yakın zamana kadar olan süreçte Kürtlerle ilgili problemler devlet nezdinde şu başlıklar altında görülmüştür: İrtica, eşkıyalık, ecnebi kışkırtması, aşiret direnci ve bölgesel geri kalmışlık. Yeğen'e göre cumhuriyet, mevzuyu bu başlıklar altında görerek Kürt sorununu etno-politik bir mevzu olarak görmemiş ve problemin asıl kaynağını gözden kaçırmıștır. Dolayısıyla bu söylemler altında Kürtlerin âdeta fiziksel varlıkları inkâr edilmiştir (2015, 126-128 266).

1930’lar itibariyle bastırılan Kürt isyanları ile Kürt milliyetçiliği 1960’lara kadar uyku dönemine girmiştir. Bu tarihlerden itibaren ise Kürt milliyetçiliği, daha çok sol bir söylem ile vücut bulmaya başlamıştır. Türkiye İşçi Partisi'nin Kürtlerin sorunları ile ilgilenmesi, Kürt hareketini sol düşünceye yaklaştıran bir faktör olmuştur. 1960'ların sonuna doğru Türkiye'nin doğusunda birçokkentte geniş kitlegösterileri düzenlenmiş ve kamuoyunun dikkati bu meseleye çekilmeye çalışılmıştır (Bruinessen, 2015, 301-302). Bu zaman diliminde resmi ve gayri resmi birçok sosyalist ve komünist Kürt örgüt kurulmuştur. PKK'nın ileride kurucusu konumunda bulunan Abdullah Öcalan'ın da üyesi olduğu Devrimci Doğu Kültür Ocakları (DDKO) bu dönemde ortaya çıkan dikkat çeken bir örgüttü. 1971'de yapılan askeri müdahale ile DDKO üyeleri genellikle yargılandılar ve hapis cezasına mahkûm edildiler (Heper, 2010, 233). 1960'lardaki Kürt hareketinin; Kürtçe eğitim, Kürt varlığının tanınması, Doğu ve Güneydoğu Anadolu bölgelerinin kalkındırılması gibi talepleri bulunmaktaydı. Ne var ki zamanla ayrılıkçı bir eğilim de ortaya çıkmıştır (Bruinessen, 2013, 5758). Bu dönemde oluşan, sonradan PKK'ya da sirayet ettiği söylenebilen yapının hem milliyetçi hem de sosyalist melez bir yapısı bulunmaktaydı. 1970’lerde Kürt aydınlarının çıkardığı yayınlarda iki önemli kavram ön plana çıkmaktadır: "Sömürge Teorisi" ve "Ezilen Ulus Milliyetçiliği". İlkine göre "Kürdistan" bölgesi, bilhassa Türkiye tarafından sömürülen bir bölgedir. İkincisine göre ise, bu "sömürgeciliğe" direnmek için Kürt halkı arasında milliyetçi bir şuur oluşturulmalıdır. Bu anlayışa göre ezen ulus milliyetçiliği "kötü" iken, ezilen ulus milliyetçiliği “iyi” olarak tanımlanmıştır. Bu şekilde hem Marksist hem de milliyetçi kalınarak bir siyasî söylem oluşturulmaya çalışılmıştır (Oran, 2008, 873, 877).

İsmail Beşikçi'ye göre 1980’lerde Kürtler arasında milliyetçi şuur gelişme göstermiştir. Beşikçi, bu durumun oluşmasında 1971 yılında kapatılan DDKO’nun etkisinin büyük olduğunu belirtmektedir $(1990,40)$. Nitekim eski DDKO üyesi Abdullah Öcalan'ın liderlik ettiği oluşum, 1978 yılında PKK (Partiya Karkeren Kurdistan- Kürdistan İşçileri Partisi) ismiyle ortaya çıkmıştır. PKK kuruluşuyla birlikte silahlı mücadele kararı almıştır ve devletle uzun sürecek bir silahlı çatışmaya girmiştir (Bozarslan, 2008, 859). PKK parti programına, Marksist ve Leninist bir çizginin yanında, aşırı milliyetçiliğin de bulunduğu bir sentezi yerleştirmiştir. Örgüte göre Kürtlerin Türkiye'de yaşadığı bölgeler Türkiye'nin sömürgesidir. Dolayısıyla 
örgüte göre, topyekûn ulusal bir kurtuluş mücadelesi verilerek; Suriye, İran, Irak ve Türkiye'nin içinde bulunduğu Kürdistan özgürleştirilmeli ve bağımsız bir Kürt ulus devleti kurulmalıdır. Bu durum PKK bildirilerinde açık bir şekilde görülmektedir. Zira bildirilerde Kürtlerin ayrı bir ulus olduğu ve özgürleștirilmesi gerektiği defaatle belirtilen bir unsurdur (Bruinessen, 2015: 308, 316; Bozarslan, 2008, 859-861).

PKK'nın özellikle 12 Eylül döneminde yaşanan işkenceler, köy yakma vs. gibi devletin şiddet içeren fiillerine karşılık, kendi şiddetini meşrulaştırıcı bir vaka olarak kullandığı bilinen bir durumdur (Oran, 2008, 878). Nitekim bu durumun PKK'nın milliyetçi söylemine şekil verdiği de söylenebilir. İsmail Beşikçi'ye göre (1991, 5557) PKK, Kürt toplumunun temel gerçekliğini ortaya koymuştur. Bu "gerçeklik" ise Kürtlerin ulus olarak ezilmiş olduğu, her bakımdan sömürüldükleri, dünya ulusları arasında onurlu bir pozisyonları olmadığıdır. PKK'ya göre Kürtler köleleşmiş, kendi gerçekliğinin ve varlığının farkında olmayan ve böyle yaşamayı artık normal gören bir halktır. Bu sebeple Kürtler, örgütlenmeli ve "sömürgeci" güçlere karşı mücadele etmeli yani savaşmalıdır. Bu sebeple PKK, kendine Kürt halkını eğitme misyonu öngörmüştür. Bu eğitmenlik rolü PKK'nın ve bilhassa Öcalan'ın kutsallaştırılmasına neden olmuştur. $\mathrm{Bu}$ eğitim sürecinde PKK, Kemalizm'in bazı sembollerini "Kürtleştirmeye" çalışmıştır. Mesela "toprak uğrunda ölenlerin olması koşuluyla vatan olabilmektedir” söylemi ön plana çıkmıştır. Üstelik PKK'ya katılan gençlerin Öcalan’a verdiği değer, Türklerin Atatürk'e verdiği değerin bir benzeriydi. Onlar için Öcalan Atatürk gibi, doğrunun, evrenselliğin, güzelin, bilimin tek referansıydı. "Apoculuk", Kemalizm'e karşı bir tür alternatifti, âdeta Kürtlügün yeniden icat edilmesiydi. PKK'nın milliyetçilik düşüncesinde ise direniş öncesi dönem, yoz, esaret dolu ve hatırlanmak istemeyen bir geçmiş olarak addedilir. Asıl Kürt tarihi ise "direniş" ile başlamaktadır. Direnişin amacı ise “Milli Kurtuluşu” sağlamaktır. PKK'nın fikriyatında olmayan veya ona doğrudan karşı olan Kürtler ise "Köle" olarak tanımlanırlar. Köle Kürtlerden nefret edilirken, halkın gerekirse zorla kölelikten kurtarılması gerektiği savunulur. PKK'ya göre şiddet kullanımı, bu şartlarda kaçınılmaz bir olgudur. Şayet Köle Kürtler kurtarılmayı reddederlerse, cezalandırılmalıdır. Örgütün kendi bünyesinde kurduğu mahkemelerde birçok Kürt'ü yargılayarak, infaz etmesi buna delalet etmektedir (Bozarslan, 2008, 862-864).

ÖzetlePKK'nın milliyetçi söylemini, büyük oranda bir tür ezilmişlik söylemi üzerinden kurduğu söylenebilir. Bunun PKK'dan önce ortaya atılan "ezilen ulus milliyetçiliği" kuramının bir tür devamı olduğu da düşünülebilir. Her milliyetçi ideolojide olduğu gibi geçmişe dönük tarihsel inşaya Kürt milliyetçiliğinde de rastlamak mümkündür. Ancak buradaki inşanın klasik kahramanlıklarla dolu tarihsel bir inşa olmadığı tespiti yapılabilir. Bilhassa PKK'dan önceki Kürt aydınlar 1800'lerdeki Kürt isyanlarını, her ne kadar bu isyanların milliyetçilik ile olan bağlantısı kısmi olsa da, "Kürt Özgürlük Hareketi" olarak değerlendirmiş ve yüceltmişlerdir (Oran, 2008, 873). PKK ise direniş öncesini kölelik olarak tanımlamış, direniş öncesi tarihi eleştiren bir bakış benimsemiştir. Bir bakıma Kürt tarihini kendisiyle başlatan, özdeşleştiren bir perspektif benimsediği söylenebilir. Bu söylenenlerin yanında Kürt milliyetçiliğine bakıldığında, birçok araştırmacının da belirttiği gibi (Bruinessen, 2015, 153; Jwaideh, 2014, 556; Oran, 2008, 872) karşıt milliyetçiliklere tepki olarak gelişmiş bir milliyetçilikle karşılaşmak mümkündür. Dolayısıyla Türkiye'deki Kürt milliyetçiliği, Türk milliyetçiliğine tepki olarak gelişmiştir. Kürt milliyetçiliğine kuramsal açıdan katkı sağlamış biri olarak kabul edilebilecek İsmail Beşikçi'nin yazıları da bu olguyu 
doğrulamaktadır. Beşikçi eserlerinde (1990; 1991), Türkiye’yi ve Kürt nüfusunun bulunduğu diğer ülkeleri (Irak, İran vs.), emperyalistlerle anlaşarak, Kürtleri bölen sömürgeci devletler olarak gördüğünü altını çizerek belirtmektedir. Bununla birlikte Beşikçi, bu ülkelerin Kürtlerin varlığını inkâr ettiğini, asimile etmeye çalıştığını, Kürtlerin ülkesi olan Kürdistanı ise böldüğünü iddia etmektedir. Beşikçi'ye göre değinilen sebeplerden dolayı bu ülkelere karşı Kürtler bir tür ulus şuuru geliştirmek ve mutlak surette milliyetçi olmalıdırlar. Dolayısıyla Beşikçi'ye göre PKK'nın da savaşı meşrudur ve haklıdır. ${ }^{6}$

\section{Sinema ve Milliyetçilik}

Kısa bir şekilde sinema ve milliyetçilik ilişkisine değinmek, çalışmanın önemini göstermek açısından faydalı olacaktır. Sinema ve milliyetçilik ilişkisinde zihinde ilk canlanan konulardan biri ulusal sinemalardır. Her ulus devletin ulusal bir sineması olması gerektiği düşünülmekle birlikte, mevzubahis sinema pratiğinin ortak bir dil konuşan (aynı ulustan) insanların arasında hızlı bir biçimde ortak bir kültür oluşturması olgusunun etkin olduğu söylenebilir (Parlayandemir, 2015, 117). Ulusal sinema kavramı en basit şekilde tanımlanacak olursa bir ulus devletin, sinematik ürünlerine atfedilen genel isimlendirmeye denilmektedir. Kısacası bir ülkenin vatandaşları tarafından ülke içerisinde üretilen, akabinde dağıtımı ve gösterimi yapılan film pratiklerine ulusal sinema denilmektedir (Butler, 2011, 132-133). Ulusal sinema ile ilgili araştırma yapan kuramcılara göre bir ülkenin ulusal sinemasından bahsedildiği vakit, hangi ülke imleniyorsa, o ülkenin sinemacıları, film üretim pratikleri zihinde canlanmaktadır. Kısacası mevzubahis ülkeye ait kimliksel nitelikler söz konusu olmaktadır (Akbulut, 2012, 29). Dolayısıyla İngiliz sineması veya Japon sineması söz konusu olduğunda, İngiliz ve Japon sinemacılar zihinde oluşmaktadır. Nitekim Japonlara ve İngilizlere ait kültürel, kimliksel özellikler düşünülmektedir (Göncü, 2016, 45). ${ }^{7}$

Bu bağlamda düşünüldüğünde ulusal sinemaların doğal bir şekilde milliyetçilikle ilișkisi bulunmaktadır. Mesela Türk sinemasının ilk zamanlarından bu yana milliyetçilik ile yakın bir ilişkisi olmuştur. Gerek ilk dönemde çekilen Kurtuluş Savaşı filmleri, gerekse sonrasında tarihsel olaylarla kurulan sinemasal ilişkiler bunu göstermektedir (Parlayandemir, 2015, 118). Serhan Mersin'in de tespit ettiği gibi $(2011,53)$ ilk dönemde çekilen Kurtuluş Savaşı filmlerinde ulus devlet anlayışının inşa etmeye çalıştığı ulusal kimliğe dair kültürel homojenleştirmeye yoğun bir şekilde rastlanmaktadır. Çünkü ilk dönemde sinema devletin kontrolünde; ulus devletin egemen kodlarını icra eden bir yapı arz etmekteydi. Örneğin bu dönemde kurulan sansür kurulu, filmlerin ulusal kültürü korumasına ve ulusal kültürü "doğru” şekilde yansıtmasını denetleyen bir konumda yer alır. Dolayısıyla bu dönemde çekilen filmler, Türk milliyetçiliğinin ideolojik muhtevasını taşırlar (İri, 2004, 257-258). Buna dair örneklere çeşitli ülkelerin ulusal sinemalarında da rastlanabilir. Örneğin Hollywood'un ilk dönemlerinde yoğun bir șekilde Western türünde filmlerinin çekildiği; bu filmlerin Amerikan mitlerine ve Amerikan ulusunun inşa ediliş sürecine odaklandıkları bilinmektedir (Gönen, 2008). Benzer şekilde Amerikan ulusunun nasıl olması gerektiği sorusuna odaklanan filmler de bulunmaktadır. Örneğin D.W. Griffith'in yönetmenliğini üstlendiği The Birth of a Nation (1915-Bir Ulusun Doğuşu) filmi bu tür bir tasavvura sahiptir. Jane M. Gaines (2005, 280-281) filmin hiçbir zaman var olmayan bir ulus modelini beyazperdeye aktardığını; sadece bazı Güneylilerin ulus kurgusunu inşa ettiğini ifade eder. 
Türk sinemasının başlangıcından bu yana milliyetçilik ile yakın bir ilişki içerisinde olmasından dolayı, Türkçe akademik literatürde yakın dönemde yapılan birçok çalışmada milliyetçilik ve sinema ilişkisinin incelendiği görülebilir. Örneğin Yüksel’in (2010) çalışmasında Bir Millet Uyanıyor (1966-Ertem Eğilmez) ve Bir Türk'e Gönül Verdim (1969-Halit Refiğ) filmleri incelenir. Her iki filmde de kadın karakterlerin üzerinden ulusal kimlik inşası yapılır ve bu kimlik pekiştirilir. Bu şekilde milliyetçi ideoloji film içinde icra edilir. Yakın dönem Türk sinemasında ise farklı türde Türk milliyetçilikleri görülmektedir. Mesut Aytekin, 2005-2011 yılları arasında Türk sinemasında milliyetçiliğin yansımasını inceler. Yazar çalışmasında Kurtlar Vadisi Irak (2006- Serdar Akar) ve Dersimiz Atatürk (2010-Hamdi Alkan) filmlerini analiz eder. Her iki filmde de milliyetçi ideoloji farklı şekillerde ortaya çıkmaktadır. Kurtlar Vadisi Irak filminde Türk-İslam sentezi üzerinden milliyetçi ideoloji kurulurken, Dersimiz Atatürk filminde Atatürk Milliyetçiliği başat bir rolde bulunur (2012, 399-401). Akaydın ve Akmeşe ise (2015, 45-46) Dağ (2012-Alper Çağlar) filmini incelerler. Yazarlara göre filmde askerlik ve militarizm gibi olgular yüceltilmektedir. Bunun yanında ötekileștirmeye başvurularak milliyetçi ideoloji inşa edilmektedir. Değinilen çalışmaların dışında, milliyetçiliği eleştiren bir yapı sunan veya "kısmen" milliyetçi ideolojiyi benimseyen filmler üzerine yapılan çalışmalar da bulunmaktadır. Örneğin Parlayandemir $(2015,127)$ Dedemin İnsanları (2011-Çağan Irmak) filmini milliyetçilik bağlamında analiz eder. Yazar filmin milliyetçiliği tartışmaktan çok milliyetçiliğin kötücül yorumlarını eleştirdiğini ifade eder. Tokdağan ise $(2013,80$ 81) Nefes: Vatan Sağolsun (2009-Levent Semerci) filmini analiz ettiği çalışmasında filmin "kısmen" milliyetçi bir yapıda olduğunu; daha çok filmde krizdeki erkek temsillerinin ön plana çıktığını ifade eder.

Kürt sineması olarak anılan filmlerin yönetmenleri de giriş kısmında değinildiği gibi, bu isimde bir sinema yapma iddiasındadırlar. Bu iddia bir bakıma ulusal sinema olma iddiası taşımaktadır. Şayet Calhoun'un (2012) yukarıda zikredilen bir ulus olmak için retoriksel iddia kuramından hareket edilirse, bu sinemacıların milliyetçiliğe ve ulus olma iddiasına uygun şekilde bir tür retoriksel iddiaya başvurdukları yorumu yapılabilir. Kaldı ki son yıllarda "Türk Sineması" ifadesi bazı çevrelerde milliyetçi bulunmaya başlamış ve bunun yerine "Türkiye Sineması" ifadesi öne çıkmaya başlamıştır (Parlayandemir, 2015,118). Kürt sinemacılar da açık bir şekilde "Türk Sineması" ifadesinden rahatsız olduklarını dile getirmektedirler. Hatta "Kürt Sineması" ifadesini kullanma motivasyonlarından birinin de bu durum olduğunu belirtmektedirler. Kısacası Kürt sineması olgusu, Kürt milliyetçiliğinin Türk milliyetçiliğine tepki olarak gelişmesi gibi, Türk sineması olgusuna tepki olarak gelişmiştir (Göncü, 2016, 77-79). ${ }^{8}$ Dolayısıyla inceleyeceğimiz filmin yönetmeni Kazım Öz'ün filmini çekerken milliyetçi motivasyonlara sahip olduğu söylenebilir. Kısacası bu filmin Kürt milliyetçiliğine dair söylemlerinin ortaya çıkarılması, bu milliyetçilik türünün sinema ile olan ilişkisini daha iyi bir şekilde idrak etmemizde faydalı olacaktır. Zira yukarıda ifade edilen çalışmalarda da görüleceği üzere, Türk milliyetçiliği ve sinema ilişkisi birçok defa akademik literatürde ele alınan bir konudur; ancak doğrudan Kürt milliyetçiliği ve sinema ilişkisini inceleyen akademik bir çalışmadan söz etmek pek mümkün değildir.

\section{Yöntem}

Filmi analiz etmek için kullanılacak teknik Van Dijk'in söylem analizidir. Van Dijk'e göre $(2003,110)$ söylemin hem üretilmesinde hem de anlaşılmasında ideolojiler 
önemli bir rol oynamaktadır. Bilindiği üzere milliyetçilik de bir ideolojidir (Yıldırım, 2011, 34). Dolayısıyla çalışma milliyetçilik gibi ideolojik bir kavram üzerine yoğunlaştı̆̆ için bu yöntem benimsenmiştir. Van Dijk'e göre söylem; konuşmaya dayalı etkileşimi, yazılı metinleri, konuşma esnasındaki vücut hareketlerini, tipografi düzenini, imgeleri ve anlamlandırmanın diğer semiyotik ve multimedya boyutlarını içeren bir iletişim etkinliğidir (Akt. Meyer, 2001, 20). Esasen Van Dijk, yöntemini haber metinleri için geliștirmiștir ve bilhassa 1980’li yıllarda Avrupa'da üretilen haberlerdeki ırkçılık ve etnik ön yargı gibi konulara odaklanmıştır (Sözen, 1999, 124-125). Bu çalışmada söylem analizinin kullanılma nedeni, "yazılı veya görsel metinlerdeki iletilerin eleştirel bir biçimde değerlendirilmesine ve anlam kavramı ekseninde okunmasına olanak sağlamasıdır. Bunu yaparken anlatıların kültürel ve toplumsal bağlam ile ilişkilendirilerek anlamlandırılmasına olanak tanımaktadır" (Bilis, 2014: s. 15). Söylem analizi, film çözümlemelerinde de kullanılan bir yöntemdir. Van Dijk'ın da ifade ettiği gibi $(2000,61)$ söylem analizinin tek, standart bir yolu yoktur. Bu sebepten olsa gerek film çalışmalarında da farklı şekillerde kullanıldığı görülebilir. Dolayısıyla araştırmacılar yöntemin belli bağlamlarından hareket ederek, inceledikleri filme nasıl uyuyorsa o şekilde hareket etmişlerdir denilebilir. ${ }^{9}$ Standart bir yolu olmasa da Van Dijk söylem analizinde şunlara dikkat edilmesi gerektiğini ifade eder:

1. Söylemin Bağlamını İrdelemek

2. Hangi grupların, güç ilişkileri ve ihtilaflar içerisinde olduğunu analiz etmek

3. Biz ve onlar hakkında olumlu ve olumsuz görüşlerin ortaya çıkarılması

4. İmaları ve ön varsayımları ayrıntılı olarak ortaya çıkarmak

5. Kutuplaştırılmış grup kanaatlerini vurgulayan tüm biçimsel yapıyı incelemek $(2000,61)$

Çalışmada söylemin bağlamı milliyetçilik ve bilhassa Kürt milliyetçiliğidir. Diğer ifade edilenlere dikkat edilmeye çalışllacak olmakla birlikte, filmi çözümlemek için takip edilecek yöntem; Bilis'in $(2014,16)$ Selam $(2013$-Levent Demirkale) filmini söylem analizine tabi tutarken izlediği yol olacaktır. Van Dijk yazılı metinler için yedi ana kategori belirlemiştir. Bunlar: Anlam, argüman, retorik, biçimsel yapı, önerme yapıları, tümce yapısı ve söylem biçimleridir. Bilis bunları film çözümlemesine uyarlarken; anlam, argüman, retorik ve biçimsel yapı olarak dört ana kategoriye indirir ve diğer kategorileri, ana kategorileri destekleyecek şekilde tasnif etmeye çalışır. Bu çalışmada da aynı yol takip edilecektir. Bilis'in çözümlediği şekilde yapılmaya çalışılacak olmasının sebebi, Bahoz /Fırtına filminin bu çözümleme şekline uygun bir film olduğunu varsaymamızdan kaynaklanmaktadır. Ayrıca Bilis'in uyarladığı şeklin daha ayrıntılı bir çözümleme imkânı sunması da çalıșmanın bu tür bir çözümleme benimsemesine neden olmuştur. Öte yandan film ve araștırılan mevzu farklı olduğu için, analiz bu bağlama uygun bir vaziyete taşınmaya çalışacaktır. Dolayısıyla bazı kategoriler filme uymadığı için çıkarılırken, bazı kategoriler de aynı veriyi sağladığı için birleștirilmiştir.

\section{Bahoz/Fırtına Filminin Milliyetçilik Bağlamında Söylem Analizi}

\section{Anlam}

\section{a. Başlıklar ve Konular}

Söylemin anlamı, söylemde yer alan sözcük veya cümlelerin anlamları ile sınırlanamaz. Söylemin teması veya bir konusu vardır. Bunlar söylemin ne ile ilgili 
olduğunu anlatırlar. Bu konular ise bir tür önermeler açısından ifade edilebilir. Gazete manşetlerinde, alıntılarda, özetlerde ifade edilirler (Van Dijk, 2003, 5859). Dolayısıyla bu bölümde filmin kısa bir özetini vermek ve ilk etapta görülen olguları anlatmak yerinde olacaktır: Bahoz / Fırtına filmi 1990'ların yoğun politik atmosferinde geçmektedir. Tunceli bölgesinde yaşayan Kürt Alevi genci olan Cemal Öztürk, üniversiteyi kazanarak İstanbul'a gelir. İlk zamanlar siyasî gruplardan uzak durarak âdeta apolitik bir karakter profili çizen Cemal, tanıştığı Kürt sol grup (Kürt Yurtseverler) aracılığıyla zamanla asimile edilmiş bir birey olduğunun farkına varır ve grubun içinde etkin bir şekilde yer almaya başlar. Cemal grubun içinde yeni arkadaşlıklar kurar ve ekibin önemli bir üyesi hâline gelir. Çeşitli sokak eylemlerine de imza atan Cemal ve arkadaşları; polisin (özellikle 69 lakaplı komiserin) yoğun baskıları, işkenceleri sonucunda filmin sonlarına doğru dağılır. Grubun bir kısmı polisin elinden kaçarken, büyük çoğunluğu yakalanır ve hapishaneye girer. Polis, Cemal'i -diğer arkadaşlarına ulaşmak için- serbest bırakır. Bu durumdan yararlanan Cemal, polisten kaçar ve memleketi Tunceli'ye geri döner. Cemal yaşadıkları sonucunda çözümü silahlı mücadele vereceği "dağa" çıkmakta arar. Film Cemal'in dağa çıkacağının belirtilmesi ile sona erer.

Filmin konusuna ilk etapta bakıldığında, 1990'larda üniversitedeki Kürt siyasî hareketi; asimile olmuș, Kürt kimliğini reddeden Cemal karakteri üzerinden anlatılmaya çalışmaktadır. Cemal, zamanla Kürt olduğunun şuuruna erişir; kimliği ve halkı (ulusu) için mücadeleye etmeye karar verir.

Kürt milliyetçiliğinin, Türk milliyetçiliğine karşı tepki olarak geliştiği (Bruinessen, 2015, 153; Jwaideh, 2014, 556; Oran, 2008, 872) filmde açlk bir şekilde görülmektedir. Cemal, asimile edilmiş bir bireydir ancak Kürt olduğunun farkına varır ve Kürt kimliği için mücadele eder, yani asimile edilişine tepki gösterir. Dolayısıyla bir Kürt milliyetçisi haline evirilir. Filmin sonunda Cemal dağa çıkarak PKK'ya katılır. Bu sürece kadar Cemal, șehirde mücadelesini sürdürmüştür ancak polisin yoğun baskıları, işkenceleri sonucunda yani devlet şiddeti karşısında; şiddetle mukabele etmeye karar verir. Baskın Oran'ın $(2008,878)$ belirttiği gibi PKK'nın kendi şiddetini meşrulaştırmak için devletin şiddetini bahane etme durumu, filmde açık bir şekilde görülmektedir.

\section{b. Aktör Tanımlama}

Söylemin anlamı önermelerle kurulmaktadır. $\mathrm{Bu}$ anlam içerisinde doğru veya yanlış yargısı içeren ifadeler mevcuttur. Önermelerin savları ise çeşitli rollerdeki aktörler, failler, üzerinden kurulur veya onlarla ilgili olabilir. Aktörler, tek bir birey olabileceği gibi bir grup da olabilir. Metinde bunlar bazı niteliklerle (isimleri, meslekleri, grupları, işlevleri vs. gibi) tanımlanırlar (Van Dijk, 2003, 64-65). Film Kürt milliyetçiliği söylemi üzerinden hareket ettiği için aktörler de bu bağlam üzerinden kurulmuştur. Mesela Cemal Tuncelilidir. Kürt ve Alevidir. Ailesiyle Kürtçe konuşur ancak İstanbul'a geldiğinde Kürt olduğunu israrla inkâr eder. Yurtseverler onun Kürt olduğunu hatırlattıkça Cemal "Kürt değilim Aleviyim. Hem Kürtler de Türklerin soyundan gelmiyor mu?" şeklinde cevap verir. Bu noktada Cemal üzerinden Kürtlerin ezildiği, asimile edildiği vurgulanmış olur. Dolayısıyla "sömürge teorisi" ve "ezilen ulus" (Oran, 2008, 877) söylemi vücut bulur. Aynı zamanda Kürt milliyetçiliğinin, Türk milliyetçiliğine olan tepkisi, asimilasyon söylemi üzerinden pekiştirilmiş olur. Yurtseverler ısrarla Cemal'i Kürt olduğuna ikna etmeye çalışırlar. Esasında onu, PKK'nın görüşü ile ifade edilirse "kölelik uykusundan" uyandırmaya 
çalışırlar. Anthony Smith'e göre $(1994,40)$ milliyetçilik mitinin merkezinde; ulusların uzun bir süredir uykuda olduğu, milliyetçilerin ise toplumu/ulusu bu uykusundan uyandırmaya çalışan kişiler olduğu fikriyatı yatmaktadır. Dolayısıyla Yurtseverler Kürt milliyetçisi olarak, Cemal'i derin uykusundan uyandırmaya çalışan, halkı eğiten önder bireyler olarak konumlanır. Zira normal ikna yöntemleri haricinde, Cemal'in okuması için dergiler vermeye çalıșırlar. Cemal, kimliğini kabul ettikten sonra birçok kitap okur. Nitekim filmin inşa ettiği söyleme göre "cahillikten" kurtulmuş olur. Bu şekilde PKK'nın halkı eğitme misyonu filmde açık bir şekilde vücut bulmuş olur. Yurtseverlerden Helin, Cemal'i ikna etmeye çalıșırken aralarında sert bir tartışma yaşanır. Bu tartışma esnasında sinirlenen Helin, Cemal'e sert bir tokat atar. Cemal, Helin'in yanından ayrılır ve derin düşüncelere girer. Devamında Cemal, otobüste giderken iki Kürt işçinin Kürtçe konuşmalarından dolayı otobüsten indirilmesine şahit olur. Hem Helin'in tokadı hem de bu olay, Cemal'i çok etkiler ve Yurtseverlere katılacağı olaylar dizisini başlatır. Helin attığı tokattan dolayı pişman olur ancak Cemal bu tokattan sonra milliyetçi şuura ulaşmaya başlamıştır. Dolayısıyla PKK'nın "Köle Kürt"ü kölelikten kurtarmak için zorunlu şiddet kullanımını savunması da (Bozarslan, 2008, 862-864) filmde ortaya çıkmış olur.

Cemal, Kürt olduğunun şuuruna ulaştıktan sonra Yurtseverlerin daimî bir üyesi olur. Dolayısıyla Yurtseverleri ve Cemal'i aynı şeylere ulaşmak isteyen aktörler olarak tanımlamak mümkündür. Cemal ve Yurtseverler, Kürt halkının özgürlügünü, sosyalist bir devrimle birlikte isteyen iyi niyetli gençler olarak sunulur. Grubun içinde büyük bir dostluk görülmektedir ve aralarında saygılı bir ilişki vardır. Onların başvurdukları bazı şiddet olayları dahi "eğlenceli" ve "gerekli" durumlardır. Gerçekleştirdikleri Molotof kokteyli içeren eylemden sonra, yapılan eylemi birbirlerine eğlenerek anlatırlar. Şiddet ise mecburen başvurulan bir yöntemdir zira Türk devleti ve Türk vatandaşları her daim okulda veya başka yerde onlara ya şiddet uygular ya da engel olmaya çalışırlar. Mesela otobüste iki Kürt işçisinin Kürtçe konuşması Türk yolcular tarafından engellenir ve işçiler otobüsten atılır. Cemal'in kaldığg yurtta Kürtçe konuşulmasına izin verilmez. Polis onlara Kürt olduğu için sürekli baskı yapar, dillerini konuşmasını engeller. Kısacası aktörlerin konumu üzerinden Kürt milliyetçisi söylem inşa edilir. Türk milliyetçiliğine tepki olarak gelişen Kürt milliyetçiliği onaylanmış olur. Cemal ve diğer karakterler üzerinden; Kürtlerin ezildiği, asimile edilmeye çalışıldığı gösterilmiş olur. Bu şekilde İsmail Beşikçi'nin belirttiği gibi $(1990 ; 1991)$ çözümün Kürt milliyetçiliği olduğu işaret edilir. Bu durum yukarıda anlatılan PKK'nın ezilmişlik söylemi ile de uyuşan bir durumdur. Ayrıca Kürt gençlerinin şiddet gördükleri için, şiddete başvurmaktan başka bir şanslarının olmadığı da polis ve normal halk şiddeti gösterilerek sağlanır. Dolayısıyla PKK'nın şiddetini meşrulaştırma söylemi filmde tekrar edilmiş olur.

\section{c. Kutuplaşma ve Karşıtlıklar}

Yukarıda da ifade edildiği gibi Van Dijk'in söylem analizinde kutuplaştırılmış grup kanaatlerini incelemek, dolayısıyla biz ve onlar hakkında olumlu ve olumsuz ifadeleri, görüşleri ortaya çıkartmak çok önemlidir. Filmde biz ve onlar karşıtlığı açık bir şekilde Kürt milliyetçisi söylemini güçlendirecek bir şekilde bulunmaktadır. Milliyetçilik kuramlarından hatırlanacağı üzere, milliyetçi ideoloji "dost ve düşman” karşıtlığı oluşturmaktadır. Dostlar ortak duyguları, ruhu, vatanı, tarihi paylaşanlar olurken; potansiyel düşmanlar öteki milletlerden gelen farklı tarihsel ve kültürel varoluş biçimleridir. Yurtseverler aynı duyguları paylaşan; Kürt halkının 
bağımsızlığını, sosyalist bir devrimle birlikte arzulayan bir gruptan oluşmaktadır. Aynı amacı paylaştıkları gibi aynı kültürü de paylaşmaktadırlar. Zira aynı müzikleri, eğlence tarzını sevmekte ve en önemlisi aynı dili (Kürtçe) konuşmaktadırlar. Gellner'ın (1992) kuramından hareketle yorumlanırsa, milliyetçi ideolojiye uygun şekilde ortada bir tür kültürel birliktelik vardır. Hatırlanacağı üzere Anderson (2011) ve Gellner gibi kuramcılar ulus inşasında dilin önemine dikkat çekerken, Hobsbawn (1993) ise dilin doğrudan "biz ve onlar" karşıtlığını sağladığını ifade etmekteydi. Filmde yer alan Kürt karakterler hem Kürtçe hem de Türkçe konuşmaktadırlar. Ancak Kürtçeyi sadece kendi aralarında konuşmaktadırlar. Diğer taraftan filmde yer alan Türk karakterler (polisler, öğrenciler, otobüsteki insanlar) sadece Türkçe konuşmaktadırlar. Dolayısıyla zıt kutuplar, filmde ilk olarak dil üzerinden inşa edilir. Ayrıca karakterler Kürt olduklarını her firsatta dile getirmektedirler. Polis, Cemal'e işkence ederken "hangi ulustan olduğunu" sorar. Cemal ise "Kürdüm" cevabını verir. Cemal'in bu ifadesi, Craig Calhoun'un (2012) yaklaşımı ile değerlendirilirse, ulus olmak için gerekli retoriksel iddianın filmde vücut bulmasıdır. Bunun ötesinde filmde gösterilen sebeplerden dolayı Türk-Kürt karşıtlığı oluşturulduğu açıktır. Kürt karakterler sosyalizm, özgürlük gibi olguları isteyen, saygıll, kibar sayılabilecek insanlardan oluşurken; Türk karakterler ise tam aksi yönde konumlanmaktadırlar. Türk karakterler; polis, öğrenci ve otobüsteki insanlardan oluşmaktadır. Polisler, başta komiser 69 olmak üzere, işkence yapmaktan hoşlanan, küfürbaz, cinsiyetçi şakalar yapan karakterlerdir. Türk öğrenciler ise iki farklı şekilde temsil edilmektedir: Birincisi Türk soluna mensup öğrenci grubudur. Türk solundaki öğrenciler, Yurtseverler ile nispeten iletișim kuran insanlardan olușmaktadır. Ancak son kertede aralarında bir birlik yoktur. İdeolojik olarak anlaşamadıkları noktalar bulunmaktadır. Bunu aralarında gerçekleşen tartışmalardan anlamak mümkündür. Filmdeki bu unsuru, Kürt hareketinin 1960'larda Türk solu ile ittifak halinde olmasına ancak sonrasında ayrılarak kendi başına var olmasına benzetmek mümkündür. Diğer Türk öğrenciler ise daha çok apolitik, şımarık öğrenci temsillerinden oluşmaktadır. Örneğin, Cemal okula ilk geldiğinde Emel ve arkadaşları ile tanışır. Emel'in siyasî bir yanı yoktur. Emel'in arkadaşları ise Cemal ile alay ederler ve "kıro" ifadesiyle onu aşağılarlar.

Yurtseverlerin arasında VK kod ismiyle tanınan tekbir Türk karakter bulunmaktadır. VK da Yurtseverlerden Abdülbaki'nin ifadesi ile "Kürtleșmiştir" ve "Kürt kişiliğinin derin özelliklerine" sahiptir. Filmin söylemi içerisinde VK farklı bir etnikten olsa da aynı duyguları, düşünceleri, kültürü paylaştığı için Kürt ulusu içerisinde kabul edilmektedir. Yurtseverlere ihanet eden tek bir kişi bulunmaktadır. 0 da film boyunca sert bir milliyetçi söylemi bulunan Müslüm'dür. Müslüm filmin sonuna doğru, 69 ve ekibinin yaptığı işkencelere dayanamayarak itirafçı olur ve grup tarafından "hain" olarak damgalanır. Yurtseverlerin, PKK ile bağlantısını sağlayan Halil, Müslüm'ü kast ederek "hainleri bol olan bir halkız" der. Filmde sürekli özgürlük ve sosyalizm arzulayan ve bundan dolayı mazlum durumuna düşen Kürt karakterler "iyi bireyler" olarak konumlanmaktadırlar. Devletle anlaşan Kürt karakter, "kötü" olarak konumlanırken; "Kürtleşmiş Türk" ise "iyi" olarak konumlanmaktadır. Devlet ise filmde, Kürt milliyetçiliğinin sömürge kuramına uygun şekilde (Oran, 2008; Beşikçi, 1990) bașta dilleri olmak üzere Kürtleri "sömürgeleştiren" bir yapı olarak konumlanır. Bunu Helin ve Ali arasında geçen "Dersim-Tunceli" mevzusundan açık bir şekilde anlamak mümkündür. Özetle filmde milliyetçi "Kürt” bireyinin-kimliğinin yüceltilmesi bulunurken, milliyetçi 
olmayan "köle" veya devletle anlaşan "Hain Kürt'ün ise yerilmesi, küçültülmesi durumu bulunmaktadır. Bu söylem PKK'nın tasavvur ettiği milliyetçi yapı ile uyum gösterir.

\section{d. Tanım ve Ayrıntı Derecesi}

$\mathrm{Bu}$ kısımda "biz ve onlar" karşıtlığının ayrıntılı bir şekilde tanımlanma veya tanımlanmama durumuna bakılır. Yani metinde "bizim" iyi taraflarımız hakkında daha belirgin, ayrıntılı bir tanım yapılırken, hatalar hakkında belirsiz, ayrıntıya girilmeyen bir tanım yapılır. Diğer taraftan "onlar" hakkında kötü olgular daha belirgin ve ayrıntılı verilir. Onların iyi tarafları ise muğlak bir şekilde aktarılır (Van Dijk, 2003, 59). Yurtseverler her daim mazlum, ezilmiş, asimile edilmeye çalışılan bir halkın çocukları olarak konumlanırken, Türklerden oluşan polisler ise işkence yapmaktan zevkalan, cinsiyetçi şakalaryapan, küfürbaz karakterlerden oluşmaktadır. Polisler gerçekleştirdiği fiilleri salt bir şekilde yapan, neden yaptığını sorgulamayan karakterlerden oluşmaktadır. Yani fiillerini kişisel olarak gerçekleştirme motivasyonları belli değildir. Dolayısıyla Mesut Yeğen'in (2015) devletin Kürt meselesini görme şekilleri olarak nitelendirdiği; irtica, eşkıyalık, ecnebi kışkırtması, aşiret direnci ve bölgesel geri kalmışlık gibi unsurlar Türk karakterlerin temsilinde ortaya çıkmaz. Yurtseverlerin iyi yanları ön plana çıkartılırken, Müslüm'ün devletle anlaşması haricinde kötü sayılabilecek bir özeeliği yer almaz. Diğer taraftan Türk polislerin işkence yapması, küfür etmesi ayrıntılı ve defaatle filmde yer alır. Türk solundan öğrencilerin kısmen iyi olma sebebi ise sosyalist olmalarına bağlanırken; bu karakterlerin başka iyi vasıfları görülmemektedir. Nitekim Türk soluna mensup öğrencilerde muğlak bir durum bulunmaktadır. Bu ifade edilen ayrıntılı veya muğlak durumlar filmin milliyetçi söyleminin inşa edilmesinde önemli bir işlev görmektedir.

\section{e. İmalar ve Varsayımlar}

Söylem üretimi bir olay hakkında sahip olduğumuz zihinsel modellere yani bilgilere dayalıdır. Metinde yer almayan bilgi, çözümleyici tarafından genel sosyokültürel bilgisi aracılığıyla çıkartılabilir. Dolayısıyla metinde ima edilen veya varsayılan bilgi ortaya çıkarılabilir. Genellikle insanlar (biz) olumlu imajlarıyla uyuşmayan bilgiyi örtük bırakmaya; düşmanlar (onlar) hakkındaki kötü olguları ise büyük bir açıklıkla ifade etmeye meyillidirler (Van Dijk, 2003, 60).

Filmde PKK'nın uyguladığı şiddet, üzeri örtülen daha çok ima edilen bir olgudur. Hiçbir şiddet içeren eyleminden söz edilmez. PKK'nın 1990'lı yıllarda uyguladığı şiddet; sivil-asker binlerce insanın ölümüne neden olduğu saldırılar filmde yer almaz. Yurtseverler, Molotof kokteyli içeren bir eylem yaparlar ancak bunu da eğlenceli ve yapılması gereken bir olgu olarak kabul ederler. Öte yandan devletin uyguladığı şiddet her fırsatta ön plana çıkarılır ve detaylandırılır. Söz konusu şiddet gösterilerek PKK'nın uygulayabileceği şiddet, meşrulaştırılmaya çalışılır. Dolayısıyla PKK'nın uyguladığı şiddet, zorunlu bir şiddet olarak telkin edilir. Bu şekilde Kürt milliyetçiliğinin Türk milliyetçiliğine tepki olarak geliştiği yinelenmiş olur. Ayrıca Kürt milliyetçiliğinin ileri sürdüğü teze uygun olarak ezen milliyetçiliğin kötü (Türk), ezilen milliyetçiliğin (Kürt) ise iyi olduğu vurgulanmış olur.

Orhan'ın Cemal ile sohbet ederken, “Çok talihsiz bir kuşağız, sevgili atalarımız her iși bize bırakmış" demesi, PKK'nın Kürt tarihi hakkındaki tezine dair bir imadır. Yukarıda ifade edildiği gibi PKK'nın milliyetçilik düşüncesinde direniş öncesi dönem eleştiri (Bozarslan, 2008, 862-864) konusudur. Bu dönem yoz, esaret dolu 
ve hatırlanmak istemeyen bir geçmiş olarak addedilir. Asıl Kürt tarihi ise direniş ile başlamaktadır.

\section{f. Örnekler ve Açıklamalar}

Metinde "biz ve onlar" hakkında ifade edilen iyi veya kötü örnekler verilir, açıklamalar yapılır. Bu örnekler ve açıklamalar söylemi desteklemeye hizmet eder (Van Dijk, 2003, 63). Filmde milliyetçi söylemi destekleyecek örnek ve açıklamalar mevcuttur. Mesela Cemal'in Kürt olması ve Kürtçe konuşmasına rağmen, Kürt olduğunu ilk kertede inkâr etmesi, Kürtlerin devlet tarafından asimile edilmeye çalışıldığına dair bir örnektir. Bununla birlikte Cemal'in ve diğer Yurtseverlerin işkence görmesi, Orhan'ın polis tarafından öldürülmesi, Kürtlerin ezildiğine ve mazlum durumuna düştüklerine dair örneklerdir.

\section{g. Yadsıma ifadeleri}

Bir olguyu sözde tasdik etmeyi veya karşı çıkmayı ifade eder. Van Dijk'e göre (2003, 63-64) bu ifadeler bir durumu kabul eder, onaylar gibi gözükürken tam aksini belirtmeyi ifade etmektedir. Mesela "Sorunları olabilir ama..." sözde empatiyi, "Çok akıllı olabilirler, ama..." sözde kabul etmeyi ifade eder. Örneğin "Özür dilerim ama..." sözde özür dileme anlamını ihtiva etmektedir. Yani özür diler gibi görünüp hemen arkasından kendisini haklı çıkarma veya haklı olduğunu düşündüğü durumları tekrar etme anlamına gelmektedir. Filmde yadsıma durumuna en büyük örnek şiddet kullanımını, sözde telin etme durumudur. Yurtseverler sürekli olarak Cemal'e Kürt olduğunu telkin ederek onu "uyandırmaya" çalışırlar ancak Cemal bir türlü ikna olmaz. Son olarak Helin, Cemal ile konuşur ancak yine ikna edemez. Aralarında çıkan tartışma sonucunda Helin, Cemal'e sert bir tokatatar. Helin bu hareketinden pişmanlık duyar ve Yurtseverlerin diğer üyeleri de bu davranışın doğru olmadığını belirtir. Ancak Cemal kimliğine dair düşünceleri, Helin'in tokadından sonra oluşmaya başlar ve Kürtler hakkında kitaplar okur. Hatta İsmail Beşikçi'nin “Devletlerarası Sömürge Kürdistan" kitabını dahi okur. Dolayısıyla şiddetin yanlış bir şey olduğu savunulur gibi yapılarak aslında şiddetin gerekli olabileceği fikri ön plana çıkarılır. Bu durumu grubun kendi arasındaki konuşmalar da doğrulamaktadır. Grup bir evde toplanmış vaziyette, Helin'in Cemal'e attığı tokadı tartışmaktadır. Müslüm “Ya, arkadaşın tokat atması tabii doğru değil ama Cemal'in yaklaşımı da doğru değil! Adam tam bozulmuş bir tip!" der. Helin ise "Arkadaşların eleștirilerini anlıyorum. Duygusal bir davranıștı ama Cemal'in gerçeği de halkımızın gerçeğinden farklı değil. Maalesef halkımızın kendi varlığını kabul edebilmesi için bazen zora ihtiyaç olabilir" demektedir. Böylece filmde hem uygulanan şiddet küçültülmeye çalışılır, hem de PKK'nın “Köle Kürt"ü uyandırmak için mecburi bir şiddete başvurma söylemi pekiştirilir.

\section{h. Geleneksel Temalar}

Geleneksel temalar daha önce tanımlanmış olan konular gibidir. Standartlaştırılmış ve kalıp yargı (stereotip) yapıları içermektedir (Van Dijk, 2003, 67). Filmde ön plana çıkan geleneksel temalar: Kürtlerin ezilmiş, mazlum, asimile edilmeye çalışılan bir halk olduğudur. Kürt milliyetçiliğinin bu sebeplere tepkiden dolayı ortaya çıtığı ve geliştiğidir.

\section{Argüman}

"Argüman; söylemin inandırıcı ve güçlü olması için kanıtsallığa, (...) söylemi değer ve normlara dayandırmaya, karşılaştırmalar yapmaya ve empati kurmaya dayalı bir söylem kategorisini oluşturmaktadır" (Bilis, 2014, 20). 


\section{a. Kanitsallık}

Söylemi güçlendiren unsurlardan biri de çeşitli kanıtlar sunulmasıdır (Van Dijk, 2003, 65). Filmde Kürt milliyetçisi söyleminin haklılığını göstermek için, Kürt karakterlerin işkenceye uğradığl, hor görüldüğü, öldürüldüğü, asimile edilmeye çalışıldığı gösterilir.

\section{b. Karşı Gerçeklik}

"Diyelim ki oldu o zaman ne olacak?" sorusu karşı gerçekliği tanımlayan standart bir formüldür. Insanlar yaptıklarından başka bir seçenek seçselerdi ne olurdu sorunsalını ortaya çıkarır (Van Dijk, 2003, 83). Cemal, Yurtseverlerin bütün çabalarına rağmen, Kürt kimliğini ısrarla reddeder. Bu inkâr sürecinde derslerine devam eden; çalışkan, babasının ifadesiyle "devletin ona verdiği fırsatı iyi değerlendiren" bir bireydir. Yurtseverlere katıldıktan sonra ise derslerini aksatan, okul ile sadece eylemsel faaliyetler sebebiyle işi olan bir bireye dönüșür. O halde, Cemal'in Yurtseverlere katılmadığı bir karşı gerçeklik düşünebiliriz. Bu durumda Cemal, devletin ona biçtiği kimlikle, PKK'nın tezi ile "Köle Kürt" olmaya devam edecek, Türk olduğuna inanacak ve hayatını bu şekilde yaşayacaktı. Cemal'in derslerden koparak okuldan uzaklașması, Althusserci (2014) bir yaklaşım ile düşünülürse devletin her türlü ideolojik aygıtını reddettiği ve bir tür mücadeleye girdiği anlamına gelmektedir. Dolayısıyla film devletin her türlü ideolojik aygıtına karşı da bir mücadele gerektiğini öne sürmektedir. ${ }^{10}$ Çünkü aksi durum "köleleșme" anlamına gelmektedir.

\section{c. Karşılaştırmalar}

İki olguyu veya grubu karşılaştırarak bir tür muhakeme yapılmasıdır (Van Dijk, 2003, 82). Film doğrudan karşılaştırmalar yapmaz. Ancak temsil boyutunda iki farklı temsil sunarak, seyirciye karşılaștırma yapmasını telkin eder. Mesela Kürt karakterlerin neredeyse tamamına yakını, özgürlük, sosyalizm gibi arzuları olan, pek şiddet yanlısı olmayan karakterlerden oluşmaktadır. Öte yandan Türk karakterler (bilhassa komiser 69 ve diğer polisler) küfürbaz, cinsel içerikli şakalar yapmayı seven, şiddet uygulamaktan keyif alan insanlardan oluşmaktadır.

\section{d. Otorite ve Alıntı - Tarihten Dersler}

Argümanı güçlendirmek için, konu hakkındaki otoriteler referans gösterilir ya da mevzu hakkında tanıklığa sahip olanlar șahit gösterilir. Diğer taraftan tarihte yaşanmış benzer olaylar örnek gösterilebilir veya karşılaştırma yapılarak, argüman güçlendirilmeye çalışılır (Van Dijk, 2003, 87-92). Film 1990’ların yoğun siyasî atmosferinin yanında, faili meçhullerin yaşandığı, PKK ile devlet arasındaki çatışmanın en şiddetli olduğu bir zaman diliminde geçmektedir. Örneğin Musa Anter'in öldürülmesi Yurtseverleri çok üzer ve bunun üzerine bir eylem gerçekleştirirler. Filmin gerçekte yaşanan olaylara yer vermesi, Kürt milliyetçiliğine dair söylemi güçlendirir.

\section{Retorik}

Geleneksel retorikte aliterasyonlar, metaforlar, simgeler, benzetmeler, ironiler, abartılar, örtmeceler ve diğer pek çok biçem figürü yer almaktadır (Van Dijk, 2003, 74). Bunlara dikkat etmek çözümleme esnasında önemlidir zira "biçemsel figürlerin söylemi güçlendiren, zenginleştiren bir yönü bulunmaktadır” (Bilis, 2014, 21). 


\section{a. Dramatizasyon ve Kurbanlaştırma}

Söylemin ikna ediciliğini arttırmak için olayları dramatikleştirilir hatta kurbanlaştırma ifadelerine başvurulur (Van Dijk, 2003, 85-86). Filmde hor görülme, ezilme, asimile edilme, işkenceye uğrama, öldürülme gibi olgular Kürt karakterlerin üzerinden işlenmektedir. Kürt karakterler kurbanlaştırılarak, mazlum konuma çekilmekte ve karşılığında uygulayabilecekleri şiddet de meşrulaştırılmaya çalışılmaktadır. Bu olgulardan hareket eden film, anlatısını dram yanı yüksek bir seyirliğe çevirerek seyirciyi; Kürt siyasî hareketinin, dolayısıyla Kürt milliyetçiliğinin haklılığına ikna etmeye çalışmaktadır.

\section{b. Abartma}

Abartma durumu, anlamın niteliklerini arttırmayı sağlayan söz oyunlarıdır. Metinde "Biz" olarak adlanan kesimin iyilikleri abartılır, kötülükleri ise küçültülür. "Onlar" olarak adlandırılan ötekilere ise tam tersi uygulanır (Van Dijk, 2003, 93). Filmde Türk karakterler belli kalıp yargılar içinde temsil edilirken, Cemal ve Yurtseverler aksi yönde konumlanırlar. Örneğin komiser 69 ve polisler küfür etmekten, işkence etmekten yani nedensiz şiddetten zevk duyarlar. Şiddetleri tam manasıyla bir temele bağlanmaz, sadece uygularlar. Örneğin PKK'nın gerçekleştirdiği şiddet eylemlerinden dolayı bu polislerin şiddet uyguladığı iddia edilebilir. Ancak filmde PKK'nın şiddeti sadece ima edilir, gösterilmez ve zorunlu bir yöntem olarak sunulur. Dolayısıyla polislerin şiddeti bir temele yerleşmez. Polislerin kesinlikle "iyi" denilebilecek olumlu bir niteliği de yoktur. Öte yandan Cemal ve Yurtseverler birbirlerini severler. Aralarındaki ilişkiler daha insancıldır. Mesela Cemal ve Orhan, Rojda'ya aşıktırlar. Helin ve Ali ise aşk yaşamaktadırlar. Grubun içinde eylemsel beraberliğin yanında derin bir arkadaşlık ilişkisi de bulunmaktadır. Kısacası her anlamda "iyi” görünen niteliklere sahiptirler.

\section{c. Metafor, Simge ve Benzetmeler}

Filmde bazı durumları simgeleyen çeşitli unsurlar bulunmaktadır. Örneğin Cemal'in asimile edilmiş bir birey olması açıklıkla ifade edilir. Ancak Cemal'in soyadı (Öztürk) ile bu olgu simgeleştirilir. Cumhuriyetin ilk döneminde Alevilere karşı yürütülen politikalar kimi zaman büyük çelişkiler barındırmıștır. Kurucu ideoloji Kemalizm, özellikle Alevi Kürtlere karşı paradoksal bir tutum benimsemiștir. Kemalistler bir yandan Alevileri, Türklerin İslamiyet yorumu olarak değerlendirip ve Alevileri "Öztürkler" veya "Türkler" olarak adlandırmışlardır. Öte yandan Kürt Alevilere güvenmemiş ve Kürt veya Zaza olmalarından dolayı onları "güvenilmez" olarak kabul etmişlerdir (Ateş, 2010; Bruinessen, 2005, 104). Dolayısıyla Cemal'in soyadı bu durumu simgeleyen bir unsurdur.

Filmin sonunda Cemal'in Tunceli'ye geri dönerek bir dağa doğru gittiği görülür. Bu dağ görüntüsünden örgüte katıldığı anlaşılır. Üstelik dağ, Kürdistanı simgeleyen bir görüntüdür. McDowall'a göre $(2007,3)$ mistik bir dağ görüntüsü, birçok Kürt'ün zihninde Kürdistan düşüncesini gösteren, simgeleyen bir olgudur. Film bu anlamda Cemal'in salt bir şekilde örgüte katıldığını imlemez, bunun yanı sıra bağımsız bir Kürdistan için de mücadele edeceğini, savaşacağını imler. Bu olgu Gellner (1992) ve Hobsbawn'ın (1993) düşüncelerini tasdik etmektedir. Yukarıda değinildiği üzere Gellner'a göre milliyetçi ideoloji, ulus ile devletin birbirinin nasibi olduğunu; biri olmadan diğerinin eksik, trajik olacağını savunmaktadır. Hobsbawn ise toplumsal birimden söz etmek için milliyetçilerin ulus devlete ulaşmaları 
gerektiğini belirtmiştir. Nitekim hem Gellner'a hem de Hobsbawn'a göre, Cemal'in filmin sonundaki davranışı milliyetçi ideolojiye uyan bir durumdur. Şayet Cemal'in durumu Anthony Smith'in (1994, 70-71) perspektifinden değerlendirilirse, daha farklı bir sonuç ile de karşılaşabiliriz. Smith'e göre ulusun ülke ile olan bağı fiziki ve fiilidir. Yani ortada herkesin tanıdığı bir gerçeklik bulunmaktadır. Diğer taraftan etnik topluluklarda ülke ile olan bağ tarihi ve semboliktir. Cemal'in Kürdistan ile bağlantısının daha çok sembolik ve tarihi olduğu açıktır.

\section{d. İroni}

Aşağılayıcı ve küçümseyici ifadelere denilmektedir (Van Dijk, 2003, 96-97). Filmde bu tür ifadeler ve hareketler Türk karakterler üzerinden vücut bulmaktadır. Örneğin Cemal ile yeni tanışan öğrenciler ona elini uzatırlar ancak Cemal elini uzattığı anda elini çekerler. Bununla birlikte Cemal'e "Kıro" diyerek onu aşağılarlar. 69 ve ekibinin, Cemal ve Yurtseverlere olan hareketleri son derece alaycı ve aşağılayıcıdır. Örneğin 69 ve ekibi, Cemal ve arkadaşlarına işkence yaparlar. İşkenceler çıplak bir vaziyette dövme, elektrik verme şeklinde gerçekleşir. 69 ve ekibinin yaptığı işkence Cemal ve arkadaşlarının kimliğini yok etme amaçlıdır. David Le Breton'a göre (2010, 186-190) acı vermek ve bununla itaat sağlamaya çalışmak, iktidarın bir güç gösterisidir. İktidarın gizli, gölgede kalmış bir yönüdür ve öteki üzerinde tahakküm kurma biçimidir. Ötekinin kimlik duygusunu parçalamak, yıkmak, onu bir tür eșya konumuna düşürmek temel amaçtır. Şayet işkence gören kişi savunmasız, çıplak ve sürekli olarak aşağılanıyorsa, kurban için daha travmatik bir durum oluşur. Bu aşağılama şekli cümlelere de yansımaktadır: 69, Cemal'e hangi ulustan olduğunu sorar, Cemal ise "Kürdüm" der. Bunun üzerine 69, Cemal'e sert bir tokat atar. Diğer polis ise "Abi bunun sol tarafı küsmesin" diyerek Cemal'in diğer yanağına da tokat atar. Özetle polisler bu șekilde temsil edilerek, Kürt milliyetçiliğinin mecburen sığınılmış, ezilen bir milliyetçilik olduğu tekrarlanırken, ezen milliyetçiliğin ise kötü ve sömürgeci olduğu vurgulanır. Çünkü Cemal, "Kürdüm" cevabı yerine "Türküm" cevabını verseydi, herhangi bir şiddet ile karşılaşmayacaktı.

\section{e. Yineleme}

Cümleleri yinelemek retoriği güçlendirebilecek bir unsurdur (Van Dijk, 2003, 105). Filmde milliyetçilikle ilgili ön plana çıkan yinelemeler şunlardır: Kürtlerin ezilmiş, asimile edilmiş, mazlum bir halk olduğu; bu sebeple ezilen milliyetçiliğin iyi, ezen milliyetçiliğin ise kötü olduğu. Kürtlerin uyandırılması ve bağımsızlık için savaşılması gerektiği gibi söylemler de ön plana çıkmaktadır.

\section{Biçimsel Yapı}

Metnin içinde yer alan cümlelerin biçimsel yapısı; yani önermelerin yeri, vurgusu söylemi etkilemektedir (Van Dijk, 2003, 70).

\section{a. Yapısal Vurgu}

Söylemin oluşmasındaki etkiyi anlayabilmek için filmin nasıl başladığı ve devam ettiğine bakılmaktadır (Bilis, 2014, 23). Film, Tunceli'nin bir köyünde, Cemal'in üniversiteyi kazandığının duyulması ile başlamaktadır. Bu sahnelerde Cemal'in ailesiyle ilişkisi görülür. Cemal ve ailesi kendi arasında sürekli olarak Kürtçe konuşmaktadırlar. Cemal, İstanbul'a geldiğinde Türkçe konuşmaya başlar ve kendisinin asla Kürt olmadığını Türk olduğunu iddia eder. Filmin başında Cemal'in Kürtçe konuştuğunun gösterilmesi, ancak sonrasında Kürt olduğunu inkâr etmesi 
asimilasyon söylemini güçlendiren bir olgu olarak ön plana çıkar. Cemal, asimile edildiğinin farkında dahi değildir. Bu şekilde filmin başlarında kimliksel bir çelişki izleyiciye gösterilir. Ayrıca Cemal'in gerçek kimliğinden dahi haberinin olmaması onun; milliyetçilerinin ifadesiyle bir çeşit uykuda olduğu ve uyandırılması gerektiği anlamını doğurur. Dolayısıyla PKK'nın teziyle "Köle Kürt" kavramı da bu şekilde filmde vücut bulmaya başlar. Bu durum aynı zamanda Kürtlerin ezilmişlik söyleminin açık bir ifadesidir. Devamında Cemal'in kimliğinin farkına varması (uyandırılması) ile kimliği için mücadeleye etmeye başlaması ise onun Kürt milliyetçiliğini benimsediğini gösterir.

\section{b. Eşanlamlılık ve Yeniden Anlatım}

Söylemin eş anlamlılık ve yeniden anlatım gibi, önermeler arasındaki ilişkiler açısından tanımlanan pek çok başka anlamsal özellikleri vardır (Van Dijk, 2003: 62). Filmde bazı olguların yeniden anlatılması suretiyle Kürtlerin ezildiğine dair söylem pekiştirilir. Mesela Yurtseverler, Cemal'i Kürt olduğuna ikna etmek için birçok defa uğraşırlar. Ne var ki Cemal bu durumu kabul etmez. Bu durum ezilmişlik ve asimilasyon söylemini güçlendirmektedir.

\section{c. Sözcük Seçimi ve Sözel Tarz}

Filmdeki karakterlerin sözcük seçimleri filmin Kürt milliyetçisi söylemi ile uyuşmaktadır. Örneğin Helin, Ali'ye “Tunceli” ismini kullandığı için tepki gösterir ve "Dersim Heval" der. Bunun üzerine Ali "Yani sömürgecilerin deyimiyle demek istedim" cevabını verir. Helin ise "Sömürenler dilimize de hükmediyorlar" diyerek Kürt milliyetçiliğinin "sömürge teorisini" hatırlatır. Yurtseverler kendi içlerinde Kürt tarihine ve coğrafyasına dair dersler yaparlar. Örneğin ders veren öğretmenin ifadeleri ile Kürtlerin ve Kürt coğrafyasının sömürüldüğü ima edildiği gibi Kürt ülkesi ile de sembolik bağ kurulur: "Kürdistan, çok verimli topraklara, stratejik-coğrafik konuma, kıtalararası ticaret yollarına ve zengin yer altı kaynaklarına sahip olan, orta büyüklükte bir ülkedir".

Halil'in Müslüman Gençlik grubundan Osman'a "Mazlum Filistin halkıla dayanışıyorsunuz da yani başınızdaki mazlum halkı görmüyorsunuz" demesi ise Kürtlerin ezilmiş bir halk olduğunu ifade eden bir başka göstergedir. Müslüm'ün "Biz daha özgür değiliz, (...) savaş koşullarındayız" cümleleri, Kürtlerin bağımsızlığını kazanması gereken bir halk olduğunu ifade eder.

Ayrıca Cemal'in polisten işkence görürken hangi ulusa mensup olduğu sorulduğunda "Kürdüm" demesi de Kürt milliyetçiliğini gösteren bir ifadedir. Müslüm'ün Cemal'e "sen Kürt kelimesinin hikayesini de biliyorsundur şimdi? Hani Türkler eskiden dağlarda kar üzerinde yürüyorlarmış ya! İște yürürken ayaklarından çıkan kart kurt seslerinden Kürt doğmuş!?” ifadesi de Türk milliyetçiliğinin bir tezine olan tepkiyi göstermektedir. Aynı zamanda Kürt milliyetçiliğinin, Türk milliyetçiliğine olan tepkisi gösterilmiş olur.

\section{Sonuç ve Tartışma}

Bahoz / Fırtına filminin milliyetçi, bilhassa Kürt milliyetçiliğine dair unsurlara sahip olduğu düşüncesinden yola çıkılarak yapılan bu çalışmada söylem analizi uygulanmıştır. Bu anlamda filmde Kürtlerin daima ezilen, mazlum, hor görülen, işkenceye uğrayan, öldürülen, asimile edilmeye çalışılan bir halk olduğu söyleminin ön plana çıkarıldığı tespit edilmiş ve bunun Kürt milliyetçiliğinin, bilhassa PKK'nın 
tezlerine uygun olduğu görülmüştür. Zira hatırlanacak olursa, PKK'ya göre Kürt halkı ezilmiş, asimile edilmiş, hor görülmüş, sömürülmüş ve sömürülen bir halktır. Filmde Kürtlerin kendilerinin, coğrafyalarının ve dillerinin sömürüldüğü defaatle ifade edilen ve gösterilen bir olgudur. Bu durum PKK'dan önce Kürt milliyetçileri tarafından ifade edilen ve PKK tarafından da sahiplenilen "sömürge teorisi"nin filmde vücut bulmasıdır. Ayrıca Kürtlerin ezilmişliği, mazlumluğu vurgulanarak, Kürt milliyetçileri tarafından ortaya atılan "ezilen ulus milliyetçisi" düşüncesi de filmde kendine bu şekilde yer bulmaktadır. Kürtleri ezen karakterlerin Türkler olması ise "ezen ulus milliyetçiliğinin" kötü olduğunu ifade eden bir durumdur. Yurtseverler, bu şekilde hem milliyetçi hem de Marksist olabilmektedirler. Dolayısıyla Kürt milliyetçiliğine dair farklı kuramların (Beșikçi, 1990; Beşikçi, 1991; Bozarslan, 2008; Bruinessen, 2015; Oran, 2008) doğrulandığı görülmektedir.

Bununla birlikte bazı araștırmacıların ifade ettiği (Bruinessen, 2015; Oran, 2008; Jwaideh, 2014) Kürt milliyetçiliğinin, Türk milliyetçiliğine tepki olarakgeliştiği olgusu da filmin içinde yer almaktadır. Bu anlamda filmde devletin ve Türk karakterlerin, Kürtler üzerindeki baskısı gösterilerek, Kürt milliyetçiliğinin sığınılması gereken bir liman olduğu söylemi oluşturulur. Film bu anlamda İsmail Beşikçi'nin (1990; 1991) görüşlerini onaylar ve Kürtlerin mutlak surette milliyetçi olmaları gerektiğini de belirtir. Tabii film bu tür bir söylemle birlikte, Kürt milliyetçileri için silahlı mücadelenin "gerekli" bir olgu olduğunu da ifade etmiş olmaktadır. İşaret edilen nokta ise Kürdistan'ın bağımsızlığı veya kurulması düşüncesidir. Zira filmde Yurtseverler her fırsatta sömürüldüklerinden, özgür olmadıklarından dem vurmaktadırlar. Cemal'in kimliğini kabul edene kadarki vaziyeti ise, Kürtlerin özgür olmadığına dair güçlü bir örnektir. Filmin sonunda Cemal'in bağımsız Kürdistan düşüncesi için silahlı mücadeleye girişmesi, işaret edilen noktayı altını çizerek belirtmektedir. Filmdeki bu olgu, Gellner'ın (1992) milliyetçi ideolojilerin bağımsız devlete ulaşma arzuları olduğuna dair görüșünü de doğrulamaktadır. Ancak Smith'in (1994) perspektifinden bakılırsa, Yurtseverler ve Cemal'in milliyetçilikleri bir ulus milliyetçiliğinden çok, etnik milliyetçiliktir. Çünkü Smith ülke ile olan bağın, etniklerde sembolik ve tarihsel olduğunu belirtir. Cemal'in Kürdistan ile olan ilişkisinin sembolik ve tarihsel olduğu, filmin kurduğu evren ve tarihi süreç bakımından açıktır. Diğer taraftan Calhoun'un (2012) ulus olmak için retoriksel iddia görüşünden hareket edilirse, filmdeki milliyetçiliği ulus milliyetçiliği olarak da değerlendirmek mümkündür. Çünkü Cemal, hangi ulustan olduğuna dair soruya "Kürdüm" cevabını vermiștir. Ayrıca Calhoun, ulus olabilmek için kolektif projeler için insanları harekete geçirmenin önemine değinmiştir. Yurtseverlerin kolektif bir amaç uğruna hareket ettikleri de bellidir. Mesela devlete karşı geldikleri gibi, Cemal örneğinde görüleceği üzere, okul gibi ideolojik bir aygıtı da reddetmektedirler. Kısacası bu nokta Smith veya Calhoun'un görüşlerine göre değişmektedir.

Filmin içinde PKK'nın halkı eğitme ve kölelikten kurtarma görüşlerini doğrulayan (Bozarslan, 2008) bir yapı da bulunmaktadır. Zira Yurtseverler, Cemal gibi asimile olmuş bir Kürt için büyük bir çaba harcarlar, onu eğitmeye ve kölelikten kurtarmaya çalışırlar. Bu durum, Smith'in (1994) milliyetçilik mitine dair ifade ettiği; ulusların belirsiz bir süreden beri uykuda olduğu, milliyetçilerin ise onları uyandırmaya çalıştığı fikriyatının filmde ortaya çıkmasıdır. Ayrıca Gellner'ın (1992) ulusu milliyetçilerin inşa ettiğine dair görüşü de Yurtseverler üzerinden doğrulanmaktadır. Zira filmde bir grup milliyetçi, potansiyel ulusun üzerinde çaba harcamaktadırlar. 
Filmin, milliyetçi ideolojiye göre biz-öteki söylemini inşa ettiği de belirtilmelidir. Çünkü filmdeki Türk ve Kürt karşıtlığı, çeşitli fiili durumların yanında dil üzerinden de inşa edilen bir durumdur. Bu olgu Hobsbawn (1993) ve Gellner'ın (1992) görüşlerini doğrulamaktadır. Hobsbawn dilin doğrudan "biz ve onlar" karşıtlığı yarattığını ifade etmekteydi. Filmde Türk ve Kürt karakterleri ayıran en önemli unsurlardan biri de dildir. Türk karakterler sadece Türkçe konuşabiliyorken; Kürt karakterler, özellikle kendi aralarında, Kürtçe de konuşmaktadırlar. Ayrıca filmdeki Kürt karakterler aynı ortak duyguları, kültürü ve zevkleri de paylașmaktadırlar. Tek istisna sayılabilecek karakter ise, etnik olarak Türk olan VK'dır. Ancak VK, Yurtseverlerle aynı duyguları paylaştığı için "Kürtleşmiştir". Dolayısıyla filmde görülen Kürt milliyetçiliğinde etnik köken çok önemli olsa da sonradan Kürtleșen biri de onlardan sayılabilmektedir. Gellner'ın (1992) ulus olabilmek için aynı kültürü, düşünceleri ve benzer iletişim sistemini paylaşma görüşü de böylece filmde doğrulanmaktadır.

Film Anderson'ın da (2011) bazı görüşlerini doğrulamaktadır. Yurtseverlerin zihinlerinde bir Kürt ulusu imgesi olduğu kesindir. Çünkü kendi uluslarından olduklarını düşündükleri insanları da (Cemal) asimile olmalarına rağmen ikna etmeye çalışmaktadırlar. Ayrıca Cemal'in filmin sonunda silahlı mücadeleye katılacak olması, onun hiç tanımadığı insanlar için de savaşmayı göze aldığını göstermektedir.

Filmin kuramsal perspektif ile uyuşmayan tek noktası ise, Yeğen (2015)'in devletin Kürt toplumunu görme şekline dair ifade ettiği olguların filmin içinde bulunmamasıdır. Filmin bu anlamda Türk karakterleri bütünüyle motivasyondan eksik karakterler olarak sunması dikkat çekici bir noktadır. Nitekim burada ortaya çıkan söylem, Türk devletinin salt olarak kötülük barındırdığı ve tahakküm kurmak veya sömürgeleștirmek için bir sebebe ihtiyacı olmadığı üzerinden şekillenmektedir.

Özetle filmin, milliyetçi Kürt kimliğini inşa eden veya barındıran bir söylem barındırdığı aşikârdır. Filmin milliyetçi söylemi, milliyetçiliğe dair kuramcıların görüşleri ile uyum göstermektedir. Ayrıca film, Kürt milliyetçiliğinin kuramsal yapısını da ihtiva etmektedir. Filmin ulusal kimlik inşasına dair bazı önermelerde bulunduğu yorumunu yapmak da mümkündür. Ancak bunun için ulusal kimlik inşasından hareket eden bir çalışma yapılmalıdır. Üstelik diğer Kürt filmlerinin de ele alındığı daha geniş bir çalışma, Kürt milliyetçiliğinin ulusal kimlik inşasına dair daha fazla veri sağlayacaktır. Bununla birlikte Kürt milliyetçiliğinin, Türk milliyetçiliğinden geliştiği düşünülürse Bahoz / Fırtına filmi Türk milliyetçiliği bağlamında incelenirse, farklı sonuçlar da ortaya çıkabilir.

\section{Notlar}

1 Çalışmanın konusu doğrudan Kürt sinemasını / filmlerini irdelemek değildir. Ancak kısaca söz konusu sinema
pratiğini tanımlamak yerinde olacaktır. Kürt sineması 2000'li yıllarla birlikte ortaya çıktığı düşünülen ve tartışılan
bir sinema hareketidir. Farklı coğrafyalarda (Irak, İran, Türkiye, Avrupa vs.) Kürt yönetmenlerin, tamamı Kürtçe veya
önemli ölçü̈de Kürtçenin kullanıldığı, Kürtlerin odak noktasına yerleştirildiği; bilhassa yaşadıkları sıkıntıları işleyen
filmlere denilmektedir. Filmler, bu noktadan hareketle kendisine ayrı bir kimlik de oluşturmaya çalışmaktadır. Kaldı
ki Kazım Öz de Kürt filmleri yapan yönetmenler arasında kabul edilmektedir (Arslan, 2009; Çiçek, 2016, 85-86;
Göncü, 2016, 68-69; Koçer, 2014, 480-481). Örneğin Öz 2013 yılında verdiği bir röportajda, Kürt filmlerinin “çocukluk
aşamasında" tam kimliğini oturtamamış bir sinema olduğunu söylemekle birlikte, kendi filmlerini de Kürt filmleri
içerisinde gördüğünü belirtmektedir (Aydemir, 2013, 97).

${ }^{2}$ Dilimizde, ulus kelimesiyle birlikte, Arapçadan Türkçeye geçen "millet" kelimesi de kullanılmaktadır. Bernard Lewis'e göre, Aramice kökenli bir kelime olan millet, "bir söz" anlamına gelmekle birlikte, kutsal bir vahiy kitabını kabul eden topluluk manasına da gelmektedir. Kelime asli olarak etniksel bir topluluktan ziyade dinsel bir topluluğu 
tanımlamaktadır. Ancak zamanla etnik ve ulus ayrımları için de kullanılmışır (1988, 38-39). İngilizce'de nationalism olarak geçen kavram Türkçede milliyetçilik veya ulusçuluk olarak kullanılmaktadır. Millet kelimesi, Lewis'in de aktardığı gibi, daha çok dini çağrışımlar yaparken, ulus kelimesinde böyle bir çağrışım yok gibidir. Diğer taraftan millet-devlet yerine ulus devlet ifadesinin dilimizde yaygınlık kazandığı söylenebilir. Ne var ki nationalism yerine kullanılan ulusçuluk ifadesinin ise milliyetçilik kadar yaygın bir şekilde kullanılmadığı söylenebilir. Bu sebeple çalışmada ulus ve milliyetçilik ifadeleri benimsenmiştir.

${ }^{3}$ Smith ulusal kimliğin şunları intiva etmesi gerektiğini iddia eder (1994: s. 31-32): Tarihi bir toprak/ülke, ortak mitler ve tarihî bellek, ortak bir kitlesel kamu kültürü, topluluğun bütün fertleri için geçerli ortak yasal hak ve görevler, topluluk fertlerinin ülke üzerinde serbest hareket imkânına sahip oldukları ortak bir ekonomi. Etnik toplulukların da benzer özelliklere sahip olabileceğini belirten Smith, ulus ile etniğin farkını daha çok fiziki ve filli bir ülke bağlamında kurmaktadır. Bununla birlikte etnik toplulukların da teritoryal anlamda belli bir bölgeleri olabileceğini belirtir, ancak yukarıda da belirttiğimiz gibi bu daha çok tarihi ve semboliktir (1994, 70-71).

${ }^{4}$ Hani'nin şu ifadeleri, hem Kürtlerin o dönemde yaşadıklarını anlatır hem de Kürt milliyetçiliğinin prototip sayılabilecek nüvelerini sunar: "Keşke aramızda ahenk olsaydı. Eğer bizler içimizden birine itaat etseydik o Türkleri, Arapları, Farsları, onların tümünü tabiiyeti altına alırdı. Dinimizi, devletimizi mükemmelleştirir ve kendimizi ilim ve irfanda eğitirdik." (Akt. Bruinessen, 2013, 390- bazı noktalama işaretleri eklenmiştir).

${ }^{5}$ 1930'larda çıkan isyanlarda bağımsız Kürt devleti düşüncesinin olduğu söylenmektedir. Mesela Şeyh Sait isyanının arkasında, bağımsız bir Kürdistan kurma düşüncesinde olan Azadi örgütünün bulunduğu iddia edilmektedir (Oran, 2008: s. 875).

${ }^{6}$ Beşikçi'nin şu sözleri PKK'yı nasıl bir yapıda gördüğünü iyi bir şekilde özetlemektedir: "PKK'nın ortaya çıkışı, Kürtlerin tarihinde, Kuzey Kürdistanlı Kürtlerin tarihinde bu bakımdan da önemli bir dönüm noktasıdır. PKK bize şunu öğretmektedir: ulusal özgürlük için, ulusal bağımsızlık için ölmesini bilmek gerekir. Irkçı ve sömürgeci Türk Devleti'ni endişelere garkeden de, PKK'nın bu kararlı, bilinçli, bilgili tavrıdır” (Beşikçi, 1990, 147).

7 "Ulusal Sinema" kavramına dair yalın ve özet mahiyetinde bir açıklama eklemeyi tercih ettik. Çünkü bu kavram akademik literatürde üzerine yoğun tartışmaların yaşandığl; çok kapsamlı ve geniş bir alana sahiptir. Dolayısıyla bu makalenin sınırlarını bir hayli aşmaktadır. Konu ile ilgili Susan Hayward (2005), Andrew Higson (2005) gibi kuramcıların çalışmaları incelenebilir.

${ }^{8}$ Kürt filmlerinin ulusal sinema modelinde konumlandırması üzerine herhangi tanımlama girişimine, bu çalışmada girilmemektedir. Böyle bir girişim makalenin sınırlarını aşmaktadır. Konu ile ilgili mevcut çalışmalar (Arslan, 2009; Çiçek, 2016; Çiçek, 2015; Göncü, 2016; Koçer, 2014) incelenebilir.

9 Örneğin Tolga Ekinci (2014) Argo filmini, Van Dijk'in gazete haberi gibi metinlere uyguladığı şekilde, makro ve mikro boyutlara ayırarak filmin yapısına uygun bir şekilde çözümler. Nazım Ankaralıgil (2008) The Siege/Kuşatma filmini Van Dijk'ın "Biz-Onlar" karşıtlı̆ını merkeze alarak bir çözümleme gerçekleştirir. Hilal Tuğan ise (2015) Saç filmini çözümlediği çalışmasında, Tolga Ekinci gibi makro ve mikro boyutlara ayırarak filmi çözümler. Ancak oluşturduğu kategoriler, Ekinci'den çok farklıdır. Mesela Ekinci, mikro yapıda çözümlediği filme daha uygun olduğu için, "Filmin Giriş Sekansı ve Jeneriği" ve "Dış Ses" şeklinde iki kategori oluşturur (2014: s. 57) Tuğan ise (2015: s. 52) mikro yapıda karakterler, diyaloglar, temsiller, ses müzik, renk gibi birçok kategori oluşturarak bir çözümleme gerçekleştirir. Ankaralıgil ise (2008: s. 154-157) diğerleri gibi makro- mikro boyutlara ayırmaz. Bunun yerine "Biz-Onlar" karşıtlı̆ını temel alır ve filmlerin diyaloglarından hareketle bir çözümleme gerçekleştirir. Çok kısa özetlerini vermeye çalışıığımız her üç çalışma da Van Dijk'ın söylem analizini uygulamaktadır ancak biçimsel ve uygulama açısından aralarında büyük farklar bulunmaktadır.

${ }^{10}$ Althusser'e göre okul, çocuğun küçüklüğünden beri zihinsel dünyasının ideolojik olarak şekillenmesinde, egemen, kapitalist ideolojinin yerleşmesinde etkin bir gücü bulunan devletin ideolojik bir aygıtıdır. Althusser okul bahsine kayda değer bir ölçüde yer ayırarak eskiden kilisenin oynadığı rolün modern zamanda okul tarafından devralındığını belirtmiş ve okulun egemen ideolojideki gücüne dikkat çekmeye çalışmışır (2014: 60-64).

\section{Kaynakça}

Akaydın, A. \& Akmeşe Z. (2015). Milliyetçilik Söylemi Bağlamında Dağ Filmi Eleştirisi. Murat İri (Der.) Medyanın Milliyetçiliği: Milliyetçiliğin Medyası (s.35-48). İstanbul: Derin.

Akbulut, H. (2012). Yeşilçam'dan Yeni Türk Sinemasına Melodramatik İmgelem. İstanbul: Hayalperest. 
Althusser, L. (2014). İdeoloji ve Devletin İdeolojik Aygıtları. (A. Tümertekin, Çev.). İstanbul: İthâkî

Anderson, B. (2011). Hayali Cemaatler: Milliyetçiliğin Kökenleri ve Yayılması. (Çev. İ.Savaşır, Çev.). İstanbul: Metis.

Ankaralıgil, N. (2008). Van Dijk'in Eleștirel Söylem Analizinden Hareketle "The Siege- Kuşatma" Filmi Üzerine İdeoloji Çözümlemesi. S. Parsa (Ed.), Film Çözümlemeleri (s.151-166). İstanbul: Multilingual.

Arslan, M. (2009). Kürt Sineması: Yurtsuzluk, Sinır ve Ölüm. Agora: İstanbul.

Ateş, K. (2010). Türkiye'de Milliyetçilik, Yurttaşlık ve Aleviler: Öztürkler ve Heretik Ötekiler. Doktora Tezi, Ankara Üniversitesi, Ankara.

Aydemir, G. (2013). Kürt Sineması Henüz Özgün Bir Dil Oluşturamadı. Film Arası Kürt Sineması: Türkiye'de Kürt Sineması, 96-98.

Aytekin, M. (2012). Türk Milliyetçiliğinin Türk Sinemasına Yansıması (2005-2011). Doktora Tezi, İstanbul Üniversitesi, İstanbul.

Beşikçi, İ. (1990). Devletler Arası Sömürge Kürdistan. Paris: Instıtut Kurde De Paris.

Beşikçi, İ. (1991). Kürt Aydını Üzerine Düşünceler. Ankara: Yurt.

Bilis, A. (2014). Selam Filmi Örneğinde İslami Düşüncenin Sinemada Temsili. Akdeniz Üniversitesi İletişim Fakültesi Dergisi, 21, 8-27.

Bozarslan, H. (2008). Kürd Milliyetçiliği ve Kürd Hareketi (1898-2000). T. Bora \& M. Gültekingil (Ed.), Modern Türkiye'de Siyasi Düşünce: Milliyetçilik (s. 841-870). İstanbul: İletişim.

Breton, L. (2010). Acının Antropolojisi. (İ. Yerguz, Çev.). İstanbul: Sel.

Bruinessen, M. (2005). Kürtlük, Türklük, Alevilik Etnik ve Dinsel Kimlik Mücadeleleri. (H. Yurdakul, Çev.). İstanbul: İletişim.

Bruinessen, M. (2013). Ağa, Şeyh, Devlet. (B. Yalkut, Çev.), İstanbul: İletişim.

Bruinessen, M. (2015). Kürdistan Üzerine Yazılar. (N. Kıraç, B. Peker, L. Keskiner, H. Turansal, S. Somuncuoğlu, L. Kafadar, Çev.). İstanbul: İletişim.

Butler, A. (2011). Film Çalışmaları. (A. Toprak, Çev.), İstanbul: Kalkedon.

Calhoun, C. (2012). Milliyetçilik. (B. Sütçüoğlu, Çev.). İstanbul: İstanbul Bilgi Üniversitesi.

Çiçek, Ö. (2015). Türkiye'de Üretilen Kürt Sinemasında Eski ve Yeni Yöntemleri: Potansiyeller ve Riskler. Melis Oğuz, Murat Akser, Zeynep Altundağ (Der.). Türk Film Araştırmalarında Yeni Yönelimler 11 (s.63-74). İstanbul: Bağlam.

Çiçek, Ö. (2016). Kürt Sineması: Mahpusluk ve Temsiliyet. Alternatif Politika Özel Sayı: 85-99.

Ekinci, T. (2014). Argo Filmi Bağlamında Hollywood Sinemasında Söylem ve Yeni Oryantalizm. Atatürk İletişim, 6, 51-66.

Gaines, J. M. (2005). “Birthing Nations”. Mette Hjort \& Scott Mackenzie (Ed.), Cinema and Nation içinde (s. 280-297). New York: Routledge.

Gellner, E. (1992). Uluslar ve Ulusçuluk. (B. Ersanlı Bahar \& G. G. Özdoğan, Çev.). İstanbul: İnsan. 
Göncü, S. (2016). Küreselleşme ve Çok Kültürlülük Bağlamında Kürt Fillmlerinde Türk Karakter Temsilleri. Yüksek Lisans Tezi, İstanbul Üniversitesi, İstanbul.

Gönen, M. (2008). Western ve Amerika Bir Ulus-Uygarlık Kurgusu. İstanbul:Versus.

Habermas, J. (2015). Öteki Olmak, Öteki'yle Yaşamak. (İ. Aka, Çev.). İstanbul: Yapı Kredi.

Hayward, S. (2005). "Framing National Cinemas". Mette Hjort \& Scott Mackenzie (Ed.), Cinema and Nation içinde (s. 81-94). New York: Routledge.

Heper, M. (2010). Devlet ve Kürtler. (K. Göksal, Çev.). İstanbul: Doğan.

Higson, A. (2005). “The Limiting Imagination of National Cinema”. Mette Hjort \& Scott Mackenzie (Ed.), Cinema and Nation içinde (s. 57-68). New York: Routledge.

Hobsbawn, E. (1993). 1780'den Günümüze Millet ve Milliyetçilik: Program, Mit, Gerçeklik. (O. Akınhay, Çev.). İstanbul: Ayrıntı.

İri, M. (2004). Türk Sineması'nda Ulusal Kimliğin İnşası (1923-1946 Dönemi). Doktora Tezi, İstanbul Üniversitesi, İstanbul.

Jwaideh, W. (2014). Kürt Milliyetçiliğinin Tarihi: Kökenleri ve Gelişimi. (İ. Çekem \& A. Duman, Çev.). İstanbul: İletişim.

Koçer, S. (2014). Kurdish Cinema as a Transnational Discourse Genre: Cinematic Visibility, Cultural Resilience, And Political Agency. International Journal of Middle East Studies 46 (3): 473-488.

Lewis, B. (1988). The Political Language of Islam. Chicago: The University of Chicago Press.

Mcdowall, D. (2007). A Modern History of The Kurds. London: I. B. Tauris.

Mersin. S. (2011). Kurtuluş Savaşı Filmleri ve Milli Hamaset. Sinecine 2 (2), 33-56.

Meyer, M. (2001). Between Theory, Method and Politics: Positioning of The Approaches To CDA. R. Wodak \& M. Meyer (Ed.), Methods of Critical Discourse Analysis (s.14-31). London: Sage.

Oran, B. (2008). Kürt Milliyetçiliğinin Diyalektiği. T. Bora \& M. Gültekingil (Ed.), Modern Türkiye'de Siyasi Düşünce: Milliyetçilik (s. 871-879). İstanbul: İletişim.

Parlayandemir, G. (2015). Milliyetçilik ve Faillik Bağlamında Dedemin İnsanları. Sinecine, 1, 107-132.

Ryan, M. \& Kellner, D. (2010). Politik Kamera. (E. Özsayar, Çev.). İstanbul: Ayrıntı.

Smith, A. (1994). Milli Kimlik. (Çev. Bahadır Sina Şener). İstanbul: İletişim.

Sözen, E. (1994). Söylem. İstanbul: Paradigma.

Tokdoğan, N. (2013). Milliyetçilik, Militarizm ve Toplumsal Cinsiyet İlişkisini Nefes Filmi Üzerinden Okumak. Sinecine 4 (2): 69-83.

Tuğan, N. (2015). Son Dönem Türk Sinemasında Hastalık Temsilleri. Gazi Üniversitesi İletişim Kuram ve Araştırma Dergisi, 40, 48-76.

Van Dijk, T. (2000). Opinions and Idologies in The Press. A. Bell \& P. Garrett (Ed.), Approaches to Media Discourse (s. 21-63). Massachusetts: Blackwell 
Van Dijk, T. (2003). Söylem ve İdeoloji Çokalanlı Bir Yaklaşım. B. Çoban \& Z. Özarslan (Ed.), Söylem ve İdeoloji (s.13-112). İstanbul: Su.

Watson, H. (1977). Nations and States. Cambridge: Methuen \& Co.

Wollen, P. (2012). Godard ve Karşı Sinema. (Çev. H. Gürkan). İstanbul Arel Üniversitesi İletişim Çalışmaları Dergisi 3, 119-129.

Yeğen, M. (2015). Devlet Söyleminde Kürt Sorunu. İstanbul: İletişim.

Yıldırım, E. (2011). Ergenekon Ötesi Türk Milliyetçiliği. İstanbul: Hayy.

Yılmaz, A. (2015). Kürt Milliyetçiliğine Eleştirel Bir Bakış: Kürt Mülteciler ve Kürdistan Milliyetçiliği. Mülkiye, 39 (1), 37-56.

Yüksel, S. B. (2010). Sinemada Ulusal Kimliğin Pekiştiricisi Olarak Kadınlar. Selçuk İletişim, 6 (3), 85-99. 